\title{
Focus on the Three Key Enzymes Hydrolysing Endocannabinoids as New Drug Targets
}

\author{
Séverine Vandevoorde and Didier M. Lambert*
}

Unité de Chimie Pharmaceutique et de Radiopharmacie, Université catholique de Louvain, Avenue E. Mounier, 73, UCL-CMFA 73-40, B-1200 Brussels, Belgium

\begin{abstract}
The family of endocannabinoids (i.e., the endogenous agonists of cannabinoid receptors) contains several polyunsaturated fatty acid amides such as anandamide (AEA) and oleamide but also esters such as 2-arachidonoylglycerol (2-AG). These compounds are the subject of growing interest in pharmacology for their multiple therapeutic potentials. Unfortunately, they are rapidly inactivated by enzymatic hydrolysis, which prevents their effective medical use. Inhibitors of endocannabinoid degradation seem to be necessary tools for the development of endocannabinoid therapeutics. But hitting this target is inconceivable without good knowledge of the enzymes. Fatty acid amide hydrolase (FAAH) is the oldest and the best characterised enzyme involved in the degradation of endocannabinoids. Cloning, distribution in the body and crystal structure of FAAH have been described. A large number of FAAH inhibitors have also been synthesised and tested. For a long time, FAAH was considered as the only key enzyme hydrolysing endocannabinoids. But recent findings indicate that at least two other enzymes have critical role in the endocannabinoids degradation. Monoglyceride lipase participates in 2-AG degradation and some data indicate that it is the primary mechanism for 2-AG inactivation in intact neurons. $N$-palmitoylethanolamine-selective acid amidase (NPAA) is a second fatty acid amide hydrolase more active with $N$-palmitoylethanolamine, an anti-inflammatory substance. The purpose of this review is to collect and compare the catalytic properties of these 3 key enzymes hydrolysing endocannabinoids.
\end{abstract}

\section{INTRODUCTION}

The biological effects of marijuana and $\Delta^{9}$-tetrahydrocannabinol (THC), its major psychoactive component, are mediated by two cannabinoid receptors christened $\mathrm{CB}_{1}$ and $\mathrm{CB}_{2}$. Both receptors are seven transmembrane domain receptors coupled through $\mathrm{G}_{\mathrm{i} / \mathrm{o}}$ proteins. $\mathrm{CB}_{1}$ receptor has been cloned in 1990 [1] and it is abundantly found in the brain and the central nervous system [2, 3]. $\mathrm{CB}_{2}$ cloning was succeeded in 1993 [4] and this second receptor is associated with the immune system and some periphery organs like the spleen [5]. But the physiological role of these receptors does not restrict itself to the binding of the constituents of a plant. The quest for endogenous ligands for the cannabinoid receptors leads to the discovery of a family of polyunsaturated compounds derived from arachidonic acid (Fig. 1).

Anandamide (arachidonoylethanolamide, AEA) was the first "endocannabinoid" (i.e., endogenous agonist of cannabinoid receptors) isolated from brain lipid extracts by William Devane [6]. AEA shares properties with $\Delta^{9}$-THC [7] and exhibits partial agonist activity on cannabinoid receptors $\mathrm{CB}_{1}$ and $\mathrm{CB}_{2}$ in vitro $[8,9]$. AEA induces antinociception in the formalin-evoked pain [10,11], in the tail-flick model applied to rhesus monkeys [12], in non-arthritic and arthritic rats [13], in carrageenan model applied to mice [14] and rats [15], and after turpentine injection into the rat bladder [16] (for reviews about antinociceptive effects of anandamide, see

\footnotetext{
*Address correspondence to this author at the Unité de Chimie Pharmaceutique et de Radiopharmacie, Université catholique de Louvain, Avenue E. Mounier, 73, UCL-CMFA 73-40, B-1200 Brussels, Belgium; E-mail: lambert@cmfa.ucl.ac.be
}

Pertwee [17] and Rice [18]). Tremendous research on anandamide was also dedicated to its effect on cell proliferation. Anandamide induces apoptosis in human neuroblastoma CHP100, human lymphoma U937 [19] , PC-12 cells [20], human prostatic cancer cells [21], endothelial cells [22], non-differentiated CaCo-2 cells [23], breast cancer cells [24] and C6 glioma cells. However, in this last case, it is not clear whether the effect of AEA is really due to the compound itself or to its metabolite arachidonic acid [25] (for reviews about antiproliferative effect of anandamide, see Maccarrone [26] and Parolaro [27]). AEA also plays a role in reproduction [28, 29], memory processes [30-33], attenuation of cholera toxin-induced fluid accumulation [34], modulation of anxiety [35], increasing of cytochrome P450 content and activity in rat [36], modulation of epilepsy [37] and modulation of feeding [38, 39].

2-arachidonoyl glycerol (2-AG) (Fig. 1) was the second endocannabinoid discovered some years after anandamide. 2-AG was isolated from canine gut by Mechoulam et al. [40] and from brain by Sugiura et al. in 1995 [41]. In 1997, Stella et al. reported that 2-AG is present in brain in amounts 170 greater than anandamide [42]. Functional studies demonstrated later that, unlike AEA, 2-AG is a full agonist of the $\mathrm{CB}_{2}$ receptor $[43,44]$ but also of $\mathrm{CB}_{1}$ cannabinoid receptor [45]. Pharmacological properties of 2-AG include inhibition of long-term potentiation [42], inhibition of proliferation of breast and prostate cancer cells [46], induction of hypotension [47, 48], contractile action [49], neuroprotection after brain injury [50], attenuation of naloxone-precipitated withdrawal signs in morphine-dependent mice [51], stimulation of nitric oxide release [52] and stimulation of appetite of mice pups [53]. 


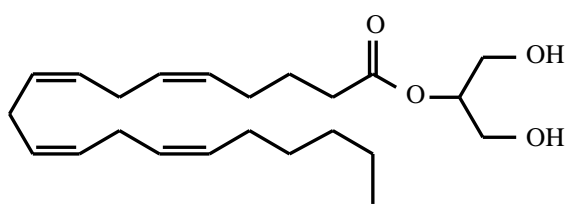

2-arachidonoylglycerol (2-AG)

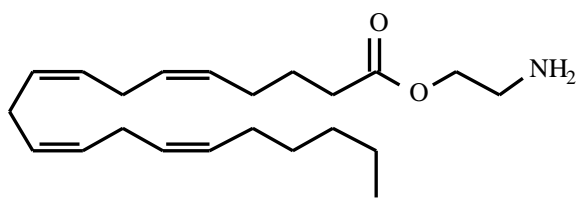

Virodhamine

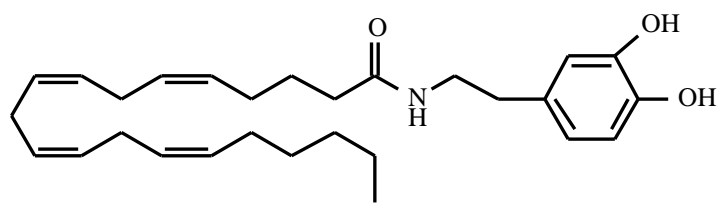

N-Arachidonoyldopamine

Fig. (1). structures of the six putative endocannabinoids

The family of endocannabinoids grew larger during the last years with the discovery of noladin ether, virodhamine, arachidonoyldopamine (NADA) and oleamide. Noladin ether was isolated from porcine brain in 2001, it only binds to the $\mathrm{CB}_{1}$ receptor [54] and it prevents, as anandamide does, neurotoxicity of the human amyloid- $\beta$ peptide [55]. Nevertheless, the endogenous existence of noladin ether was recently called into question [56]. One year later, virodhamine $(O$ arachidonoyl ethanolamine) (Fig. 1) was extracted from rat brain. It acts as a partial agonist at $\mathrm{CB}_{1}$ receptor, and full agonist at $\mathrm{CB}_{2}$ receptor [57]. In 2000, Bisogno et al. found that NADA (Fig. 1) acts as a selective $\mathrm{CB}_{1}$ agonist and it inhibits proliferation of human breast cancer cells [58]. Evidence of the endogenous existence of NADA was succeeded two years later by its isolation from rat brains and bovine dorsal root ganglions [59], which assign it the membership of the "endocannabinoids family". Finally, it has been shown recently that oleamide [60] is an endogenous full $\mathrm{CB}_{1}$ receptor agonist [61] which induces hypnotic action blocked by a $\mathrm{CB}_{1}$ receptor antagonist [62].

In addition to these endocannabinoids, other endogenous fatty acid amides ligands have been identified. They are

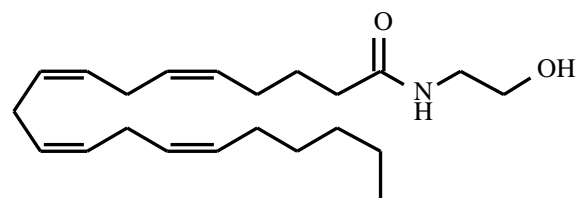

Anandamide (AEA)

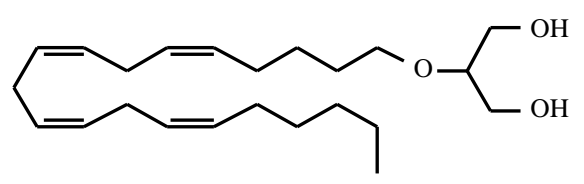

Noladin ether

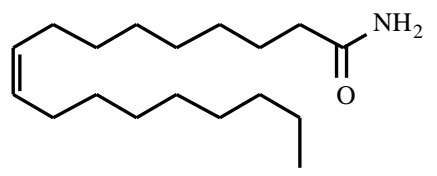

Oleamide characterised by cannabimimetic properties in vitro and in vivo; however, they are devoid of affinity for the cannabinoid receptors. It is likely that these ligands interfere with the degradation of endocannabinoids and consecutively enhance their levels and strengthen their biological actions mediated by $\mathrm{CB}_{1}$ and $\mathrm{CB}_{2}$ receptors. Such a mechanism has been described as an "entourage effect" in the literature [63]. Stearoylethanolamide (Fig. 2) has the same effects as AEA on catalepsy, motility, analgesia and body temperature but it has no affinity for cannabinoid receptors [64]. Palmitoylethanolamide (PEA) is a scheming compound, which was first attributed as an endogenous $\mathrm{CB}_{2}$ ligand. Facci reported that PEA was able to inhibit binding of $\left[{ }^{3} \mathrm{H}\right]-$ WIN 55, 212-2 to RBL-2H3 basophilic leukaemia cell membranes [65]. However, other groups, including ours, were unable to detect an interaction between $\mathrm{PEA}$ and $\mathrm{CB}_{2}$ receptor in other tissues $[66,67]$. It is now generally assumed that PEA does not bind to $\mathrm{CB}_{1}$ and $\mathrm{CB}_{2}$ cannabinoid receptors. PEA is an antiinflammatory compound, which can, after orally administration, reduce degranulation of mast cells produced by injection of substance $\mathrm{P}$ into the ear pinna [68]. PEA induces antinociception in formalin-evoked pain, which is reversed

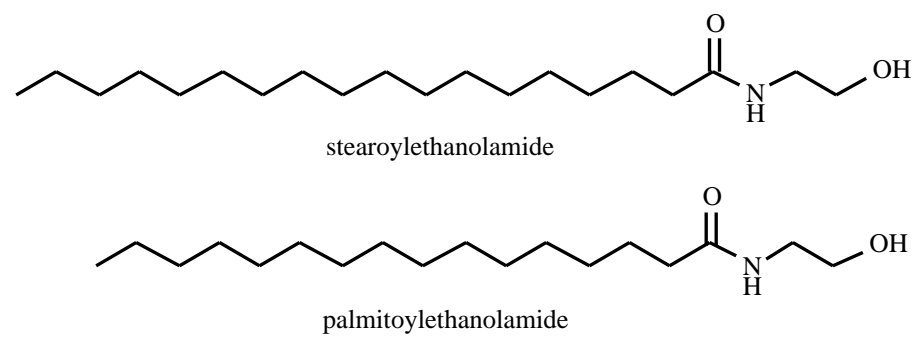

Fig. (2). Structures of stearoylethanolamide and palmitoylethanol-amide. 
by the $\mathrm{CB}_{2}$ antagonist SR 144528 [11], [69]. PEA is also effective after injection of turpentine into the urinary bladder [10] and it acts synergistically with AEA to inhibit formalinevoked and kaolin-evoked pain behaviour [69] (for reviews on the antinociceptive effect of PEA, see Lambert [70] and Walker [71]). PEA is a potent anticonvulsant, devoid of neurologic impairment, in maximal electroshock seizure test [72]. PEA also has antiproliferative properties on human breast cancer cells, by a mechanism, which involves a downregulation of the enzyme responsible for AEA degradation [73].

After the discovery of the family of endocannabinoid ligands, searchers questioned the existence of a mechanism able to terminate their signalling activity. Ten years ago, Deutsch and Chin reported the identification of an "anandamide amidase" [74] in neuroblastoma and glioma cells, which was later referred to as "anandamide amidohydrolase" in rat and porcine brains by other research groups $[75,75]$. In 1996, the purification and characterisation of an "oleamide hydrolase" by Cravatt et al. put an end to the plurality of denominations. The same enzyme was able of hydrolysing both anandamide and oleamide, and it was renamed "fatty acid amide hydrolase" (FAAH) [77]. For a long time, FAAH was considered as the only key enzyme hydrolysing endocannabinoids. But recent findings indicate that at least two other enzymes have a critical role in the endocannabinoids degradation. During the ten years elapsed after the discovery of "anandamide amidase" by Deutsch and Chin, huge progresses have been achieved in its characterisation. Cloning, distribution in the body and crystal structure of FAAH has now been described. However, the same time has allowed the identification of two other enzymes, namely monoglyceride lipase [78], which participates in 2-AG degradation, and $\mathrm{N}$-palmitoylethanolamine-selective acid amidase (NPAA) [79], for which PEA is the most active substrate.

If the synthesis of inhibitors of endocannabinoid degradation is a necessary tool for the development of endocannabinoid therapeutics, future researches will be indissociable of the entirety of the three enzymes, and will be focused on design of selective inhibitors of each of them. We propose along this review, to collect and compare the catalytic properties of these 3 key enzymes hydrolysing endocannabinoids.

\section{FATTY ACID AMIDE HYDROLASE (FAAH)}

\section{Molecular Structure}

FAAH is a membrane-bound enzyme, which belongs to the family of amidases enzymes. They are characterised by a highly conserved region rich in serine, glycine and alanine residues. This region, called "amidase signature" is common to more than 80 amidases enzymes and it corresponds to amino acids 215-257 in mammalian FAAH enzymes. FAAH from rat was first successfully cloned by Cravatt et al. in 1996. Human [80], mouse [80] and porcine [81] FAAH were subsequently cloned and have shown $73 \%$ identity at the overall amino acid level and $90 \%$ identity at the amidase signature. The FAAH proteins of these different species are all 579 amino acids in length, however their mRNAs differ in size (for more details on molecular structure of FAAH, see reviews Ueda and Yamamoto [82] and Ueda [83]). The 2.8 $\AA$ X-ray crystal structure of FAAH was reported by Bracey et al. [84] and constitutes a major progress in the understanding of the three-dimensional structure of this enzyme. This study revealed that FAAH is a dimeric enzyme with a core composed of a serine-serine-lysine triad. FAAH possesses channels to establish direct access between the bilayer and its active site, to facilitate substrate binding and products release. Recently, the characterisation of an Arabidopsis thaliana FAAH homologue was reported by Shrestha et al. [85]. Its cDNA encodes a protein of 607 amino acids with $37 \%$ identity to rat within the amidase signature.

\section{Distribution}

In rat, FAAH is mainly distributed in the liver, small intestine, brain, testis, uterus, kidney, occular tissues and spleen, but not in skeletal muscle or heart $[74,75,86]$. In human, the distribution is different: FAAH was mainly detected in pancreas, brain, kidney, skeletal muscle [80], placenta [87] and less abundant in liver [80]. FAAH activity was also detected in mouse uterus [88], and its expression is regulated during pregnancy $[89,90]$. FAAH activity was also detected in several ocular tissues including bovine retina [91], rat retina [92], porcine retina, optic nerve, iris and lacrimal glands [93]. Within the brain, activity of FAAH was the highest in globus pallidus, hippocampus, substantia nigra, cerebellum, cerebral cortex, cerebellum and the lowest in brainstem and medulla [94]. Immunohistochemical studies showed the preferentially localisation of FAAH in pyramidal cells of cerebral cortex, hippocampus, purkinje cells of cerebellar cortex and mitral cells of olfactory bulb [95]. Recently, Romero et al. performed an immunohistochemical analysis in hippocampus and enthorinal cortex sections from brains of Alzheimer's disease patients. They showed that FAAH is abundantly and selectively expressed in neuritic plaque associated astrocytes and microglia, and that its activity is elevated in the plaques and surrounding areas [96]. It is also significant to note that FAAH and $\mathrm{CB}_{1}$ receptor have complementary localisation in the retina [92], the placenta [87] and the brain [97, 98], where FAAH is preferentially located in the large neurons postsynaptic to $\mathrm{CB}_{1}[95,97]$.

In cell lines, FAAH was detected in mouse N18TG2 neuroblastoma [74, 99], rat C6 glioma [74], J774 macrophages [100], RBL-2H3 basophilic leukaemia cells [101], bronchioalveolar non-small cell lung carcinoma [74] and human neuroblastoma CHP199 [102]. However, attempts to detect FAAH failed in human epithelioid carcinoma (HeLa), human larynx epidermoid carcinoma (Hep2), human hepatocellular carcinoma (HepG2) [74] and monkey COS-7 kidney fibroblast-like cells [103]. Human embryonic kidney cells (HEK) constitute a scheming case in term of FAAH expression. If FAAH expression and activity were detected in human vanilloid receptor $\left(\mathrm{VR}_{1}\right)$ transfected HEK cells [104], Western blotting [105] and reverse transcriptase-polymerase chain reaction (RT-PCR) (Vandevoorde S, Delouvroy F and Lambert DM., unpublished result) failed to detect any expression of FAAH in non-transfected HEK cells. 


\section{Assays}

Monitoring of the hydrolysis of anandamide to arachidonic acid and ethanolamine was achieved by using of labelled, either on the arachidonoyl moiety or on the ethanolamine moiety, anandamide. When $\left[{ }^{14} \mathrm{C}\right]$ - or $\left[{ }^{3} \mathrm{H}\right]$-anandamide labelled on the arachidonoyl moiety was used, separation of the products of hydrolysis was achieved by thin-layer chromatography $[74,76,77]$ or by high-performance liquid chromatography [106]. When $\left[{ }^{14} \mathrm{C}\right]-$ or $\left[{ }^{3} \mathrm{H}\right]$-anandamide labelled on the ethanolamine moiety was used, the released ethanolamine was separated by open bed column chromatography [75], [99] or by methanol-chloroform extraction [107, 108]. Very recently, a novel high-throughput-compatible assay, based on the differential absorption of the substrate and the hydrolysis products to activated charcoal was reported [109].

Non-radioactive assays were also developed. Separation and quantification of arachidonic acid product was achieved by gas chromatography [110] and high-performance liquid chromatography (HPLC) [111, 112]. HPLC was also used for the separation and detection of released ethanolamine moiety [113]. A fluorescence assay [114], and a calorimetric assay using fatty acid $p$-nitroanilides [115] were also reported.

\section{Substrates}

FAAH is capable of hydrolysing a wide variety of substrates. Substrate specificities are dependent of enzyme preparations (from rat liver, rat or porcine brain, rat, human and porcine recombinant, N18TG2 or RBL-2H3 cells - A comprehensive table of substrate specificities of FAAH with various enzyme preparations is available in a recent review of Deutsch [116]). As an example, PEA is rapidly metabolised by enzymes from rat liver [117] and mouse N18TG2 cells [98], but hardly by enzymes from rat [75] and porcine [76] brain. However, AEA was revealed as the most active substrate in all the studies. FAAH exhibits a high amidase activity against anandamide (C20:4), stearoylethanolamide (C18:0), palmitoylethanolamide (C16:0), myristoylethanolamide (C14:0), lauroylethanolamide (C12:0), oleoylethanolamide (C18:1) and oleamide. In addition to its amidase activity, FAAH exhibits esterase activity against 2-arachidonoylglycerol (C20:4) [112], methyl arachidonate and oleoyl methyl ester. Patricelli et al. reported that FAAH hydrolyses oleoyl methyl amide and its analogue oleoyl methyl ester with equivalent catalytic efficiencies. Mutation of a single lysine residue to alanine (K142A) abolished this property and produces a mutant FAAH enzyme hydrolysing esters more than 500-fold faster than amides [118].

\section{Catalytic Mechanism}

In 1999, two distinct groups investigated the catalytic features of FAAH through mutagenesis studies. They found that three serine residues (S217, S218 and S241) are required for FAAH activity $[119,120]$. In 2000, Patricelli and Cravatt conducted a comprehensive study of mutagenesis of all potentially catalytic residues in FAAH, highly conserved in all amidase signature enzymes. They attributed some residues to primarily structural roles and they found that residues Lys-142, Ser-217, Ser-218, Ser-241 and Arg-243 are critical for amidase activity [121]. The $2.8 \AA \mathrm{X}$-ray crystal structure of FAAH recently reported by Bracey et al. [84] confirmed that FAAH is a dimeric enzyme with a core composed of a serine-serine-lysine triad. Very recently, Mc Kinney proposed a catalytic mechanism through the formation of a tetrahedral intermediate. Uncharged Lys-142 initiates catalysis by accepting a proton from Ser-217, which in turn deprotonates Ser-241 nucleophile to facilitate attack on the substrate carbonyl (scheme 1) [122].
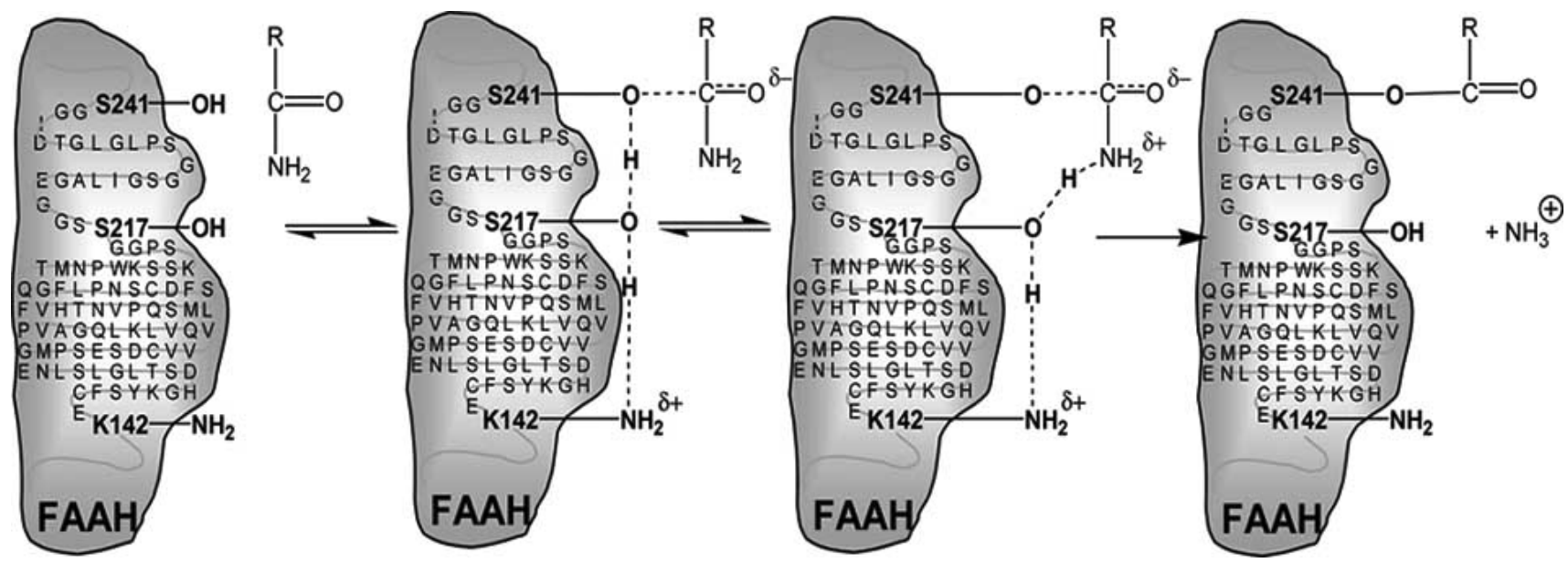

Scheme 1. Proposed mechanism for the acylation step of amide hydrolysis by FAAH. (scheme adapted from the scheme 1 of Mc Kinney and Cravatt [122]).

Successive deprotonations from Ser-217 to Lys-142 and from Ser-241 to Ser-217 (A) allow the attack of the substrate carbonyl by Ser-217, which gives a proton to the nitrogen atom of the amide group of the substrate (B). Simulaneously, Lys-142 gives a proton to Ser-217. These protons transfers induce the return of Lys-142 and Ser-217 in their initial protonation states and result in the formation of an acyl enzyme intermediate $(\mathrm{C})$. 


\section{Reversibility of Anandamide Hydrolysis}

In 1994, two research groups reported the synthesis of anandamide by condensation of arachidonic acid and ethanolamine on brain membranes. They demonstrated that the synthesis of anandamide occurs through an ATP- CoAindependent process $[123,124]$. Five years later, the equilibrium in the hydrolysis and synthesis of anandamide was demonstrated by a purified FAAH enzyme [125]. FAAH was then assumed to work not only as hydrolase, but also as anandamide synthase. However, it was also demonstrated that very high concentrations of ethanolamine and arachidonic acid are required for the synthase pathway by FAAH, and that this enzyme could not work as a synthase under physiological conditions. It is now generally assumed that the biosynthesis of anandamide occurs by a mechanism, which involves the formation of $\mathrm{N}$-arachidonoyl-phosphatidylethanolamine catalysed by a calcium-dependent transacylase, followed by the hydrolysis by a phosphodiesterase of the D type [126]. Very recently, Okamoto et al. reported the cloning of a phospholipase D responsible of AEA biosynthesis [127].

\section{Inhibitors}

The multiple therapeutic potentials of endocannabinoids are well-established. Unfortunately, these compounds are rapidly inactivated by FAAH enzymatic hydrolysis, which prevents their effective medical use. Inhibitors of FAAH seem to be necessary tools for the development of endocannabinoid therapeutics: drugs that block inactivation of endocannabinoids might be beneficial in disease states in which endocannabinoid levels are down-regulated. Inactivation of FAAH was already shown to elicit pain and anxiety [35] without the side effects (hypomotility, hypothermia and catalepsy) accompanying activation of $\mathrm{CB}_{1}$ receptors by exogenous cannabinoids like $\Delta^{9}$-THC (for reviews of therapeutic potentials of endocannabinoids, see Piomelli [128]; Fowler [129] and Cravatt [130]). To preserve this lack of "cannabinoid side effects", the inhibitors must be devoid of affinity for the cannabinoid receptors, especially for the cannabinoid receptor 1 , which is involved in most of the side effects of exogenous cannabinoids. Data on the inhibitory potential against FAAH are now indissociable of the data regarding affinity for the cannabinoid receptors. For this reason, we considered important and useful to mention the data on affinities for the cannabinoid receptor 1 for the inhibitors listed in the following tables. FAAH is characterised by an optimum alkaline $\mathrm{pH}$ ranging from 8.5 to 10 [107]. However, most of the inhibitory assays are performed at physiological $\mathrm{pH}$. Because a modification of the $\mathrm{pH}$ assay can induce drastic changes in inhibitors potencies, we also considered useful to indicate the $\mathrm{pH}$ assay in parallel of the $\mathrm{Ki}$ and $\mathrm{IC}_{50}$ values reported.

\section{IRREVERSIBLE INHIBITORS OF FAAH}

When Deutsch and Chin [74] discovered FAAH in 1993, they also observed that phenylmethylsulfonyl fluoride (PMSF) was a potent inhibitor. This observation was confirmed by Desarnaud et al. [75] in 1995. However, this well-known serine protease inhibitor was not selective for FAAH and a growing interest was rapidly shown in the design of more selective inhibitors. To reach this goal, searchers took their inspiration from the chemical structures of the substrates of FAAH, and developed derivatives of anandamide. This method allowed the discovery of methyl arachidonoyl fluorophosphonate (MAFP) [131, 132], diazomethylarachidonoyl ketone (DAK) [133], laurylsulfonyl fluoride [134], stearylsulfonyl fluoride [134], methyldodecyl fluorophosphonate [135] and very recently arachidonyl sulfonyl fluoride [136]. All these compounds are potent inhibitors of FAAH, however, they also have remarkable affinity for the $\mathrm{CB}_{1}$ receptor.

In 1998, Patricelli et al. identified 2-octyl $\gamma$-bromoacetate, an endogenous compound originally isolated from human cerebrospinal fluid, as a potent irreversible inhibitor of FAAH [137]. Interestingly, at pH 7.0, this compound was proved to be significantly more potent than oleoyl trifluoromethyl ketone (a potent transition state inhibitor of FAAH that we will discuss in the next part). In 1997, Beltramo reported that the bromoenol lactone, (E)-6-(bromomethylene) tetrahydro-3-(1-napthtalenyl)-2H-pyrano-2-one (BTNP) is a non-competitive and irreversible inhibitor of FAAH [138]. However, the affinities of these compounds for the cannabinoid receptors were not investigated.

Very recently, Kathuria et al. described a new class of FAAH inhibitors. URB597 (carbamic acid, cyclohexyl-3'(aminocarbonyl) [1, 1'-biphenyl]-3-yl ester), the most potent, does not exhibit affinity for the cannabinoid receptors. Thus, at doses that inhibit FAAH and substantially raised brain anandamide, but not 2-AG, levels, this compound does not evoke catalepsy and hypothermy. However, URB597 exhibits anxiolytic-like actions, which are prevented by $\mathrm{CB}_{1}$ receptor antagonist SR 141716A [35]. Alkylcarbamic acid aryl esters constitute a new class of inhibitors a FAAH described by Tarzia in 2003. The most potent members of this family are $N$-cyclohexylcarbamic acid biphenyl-3-yl ester and $N$-butylcarbamic acid -4-(phenylmethoxy) phenyl ester, which are devoid of affinity for cannabinoid receptors (Table 1) [139].

\section{OTHER INHIBITORS OF FAAH}

Modification of the chemical structure of substrates of FAAH does not only lead to the formation of irreversible inhibitors. In 1994, Koutek reported the synthesis of arachidonoyl trifluoromethyl ketone (ATFMK), a transition-state inhibitor of FAAH. ATFMK was able to displace the $\left[{ }^{3} \mathrm{H}\right]-$ $\mathrm{CP} 55,940$ binding to $\mathrm{CB}_{1}$ with a $\mathrm{Ki}$ of $0.65 \mu \mathrm{M}$ [140]. One year later, Patterson described the synthesis and evaluation of the trifluoromethyl ketone derivative of oleamide [141].

An alternative to transition state inhibitors is to use derivatives of the endogenous lipid palmitoylethanolamide (PEA), since this compound is able to prevent the FAAHcatalysed metabolism of anandamide (AEA) [142] and to inhibit the expression of FAAH [143]. Palmitoylisopropylamide exhibits good inhibitory potential against FAAH not only in presence of rat brain homogenates but also in intact C6 cells, in which it produces $87 \%$ inhibition of $\left[{ }^{3} \mathrm{H}\right]-$ ethanolamine production from $\left[{ }^{3} \mathrm{H}\right]-\mathrm{AEA}$, at $30 \mu \mathrm{M}$ [143]. $\mathrm{N}$-(1-Oxohexadecyl)glycine methyl ester and $\mathrm{N}$-(2-acetoxyacetyl)pentadecylamine, very recently described, inhibit FAAH with $\mathrm{IC}_{50}$ values of 10 and $8.3 \mu \mathrm{M}$, respectively 
Table 1. Irreversible Inhibitors of FAAH

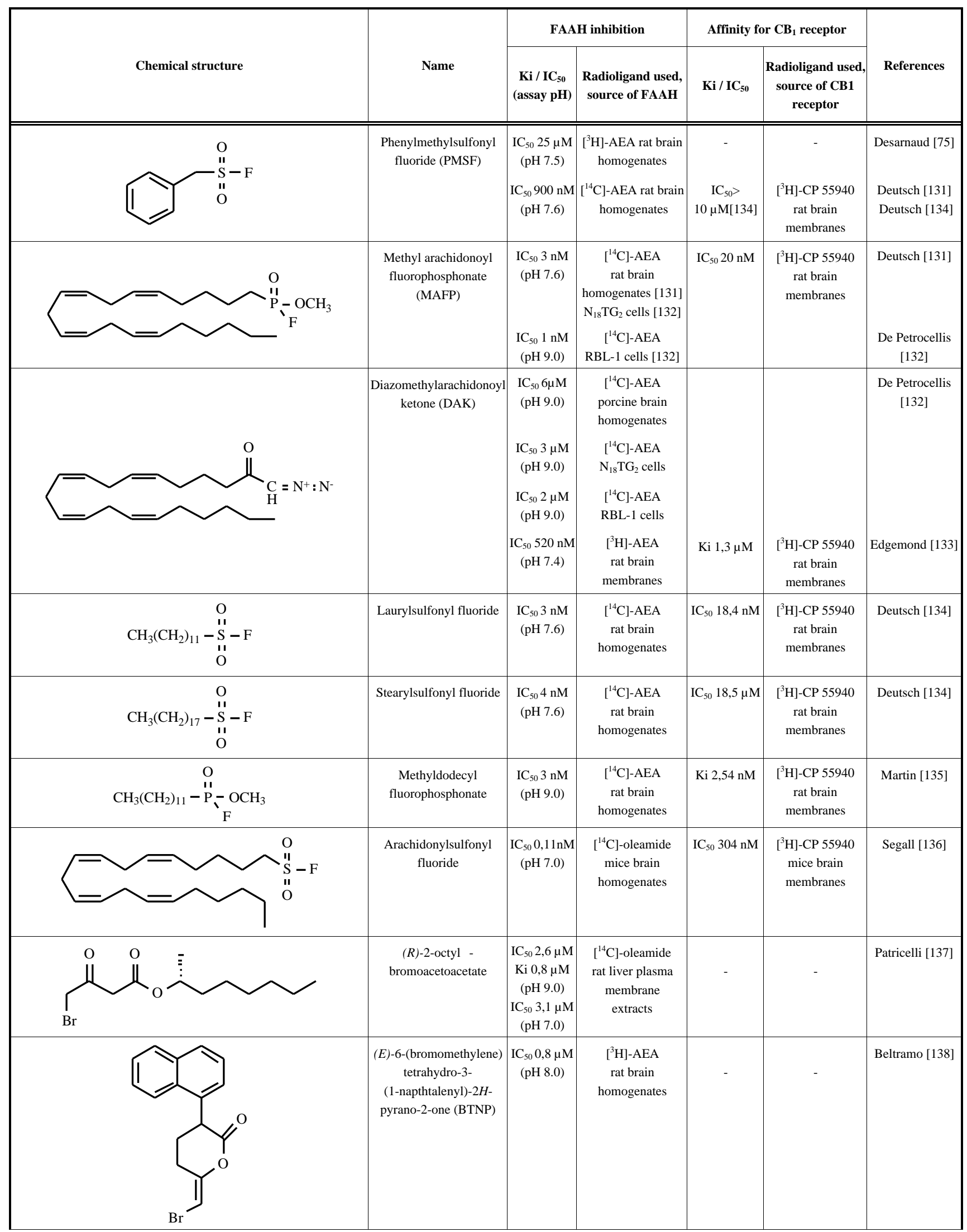


(Table 1) contd....

\begin{tabular}{|c|c|c|c|c|c|c|}
\hline \multirow[b]{2}{*}{ Chemical structure } & \multirow[b]{2}{*}{ Name } & \multicolumn{2}{|c|}{ FAAH inhibition } & \multicolumn{2}{|c|}{ Affinity for $\mathbf{C B}_{1}$ receptor } & \multirow[b]{2}{*}{ References } \\
\hline & & $\begin{array}{c}\mathrm{Ki} / \mathrm{IC}_{50} \\
(\text { assay pH) }\end{array}$ & $\begin{array}{c}\text { Radioligand used, } \\
\text { source of FAAH }\end{array}$ & $\mathrm{Ki} / \mathbf{I C}_{50}$ & $\begin{array}{c}\text { Radioligand used, } \\
\text { source of CB1 } \\
\text { receptor }\end{array}$ & \\
\hline $\mathrm{O} \leadsto \mathrm{NH}_{2}$ & $\begin{array}{c}\text { carbamic acid, } \\
\text { cyclohexyl- } \\
\text { 3'-(aminocarbonyl)[1,1'- } \\
\text { biphenyl]-3-yl ester } \\
\text { (URB 597) }\end{array}$ & $\mid \begin{array}{c}\mathrm{IC}_{50} 4,6 \mathrm{nM} \\
(\mathrm{pH} \text { not } \\
\text { mentionned })\end{array}$ & $\begin{array}{c}{\left[{ }^{3} \mathrm{H}\right] \text {-AEA }} \\
\text { rat brain } \\
\text { homogenates }\end{array}$ & $\begin{array}{c}\text { No binding at } \\
\text { concentration } \\
\text { as high as } \\
100 \mu \mathrm{M}\end{array}$ & $\begin{array}{c}{\left[{ }^{3} \mathrm{H}\right]-\text { WIN }} \\
55212,2 \text { rat } \\
\text { cerebellar } \\
\text { membranes }\end{array}$ & Kathuria [35] \\
\hline $\mathrm{n}-\mathrm{C}_{4} \mathrm{H}_{9}$ & $\begin{array}{c}N \text {-butylcarbamic acid -4- } \\
\text { (phenylmethoxy) phenyl } \\
\text { ester }\end{array}$ & $\left|\begin{array}{c}\mathrm{IC}_{50} 390 \mathrm{nM} \\
(\mathrm{pH} \text { not } \\
\text { mentionned })\end{array}\right|$ & $\begin{array}{c}{\left[{ }^{3} \mathrm{H}\right]-\mathrm{AEA}} \\
\text { rat brain } \\
\text { homogenates }\end{array}$ & $\begin{array}{c}\text { No binding at } \\
\text { concentration } \\
\text { as high as } \\
30 \mu \mathrm{M}\end{array}$ & {$\left[\begin{array}{c}{\left[{ }^{3} \mathrm{H}\right]-\text { WIN 55212,2 }} \\
\text { rat cerebellar } \\
\text { membranes }\end{array}\right.$} & Tarzia [139] \\
\hline & $\begin{array}{l}N \text {-cyclohexylcarbamic } \\
\text { acid biphenyl-3-yl ester }\end{array}$ & $\left|\begin{array}{c}\mathrm{IC}_{50} 63 \mathrm{nM} \\
(\mathrm{pH} \text { not } \\
\text { mentionned })\end{array}\right|$ & $\begin{array}{c}{\left[{ }^{3} \mathrm{H}\right]-\mathrm{AEA}} \\
\text { rat brain } \\
\text { homogenates }\end{array}$ & $\begin{array}{c}\text { No binding at } \\
\text { concentration } \\
\text { as high as } \\
30 \mu \mathrm{M}\end{array}$ & {$\left[\begin{array}{c}{\left[\begin{array}{c}3 \\
\mathrm{H}]\end{array}\right] \text { WIN 55212,2 }} \\
\text { rat cerebellar } \\
\text { membranes }\end{array}\right.$} & Tarzia [139] \\
\hline
\end{tabular}

[144]. After the finding that potency of FAAH inhibition can show $\mathrm{pH}$ dependency [145], $\mathrm{N}$-(1-oxohexadecyl)glycine methyl ester was assessed for its ability to inhibit AEA metabolism at three assay $\mathrm{pH}$ values. The $\mathrm{IC}_{50}$ values were similar at $\mathrm{pH} \mathrm{6,7.6} \mathrm{and} \mathrm{9.} \mathrm{However,} \mathrm{the} \mathrm{maximum} \mathrm{observ-}$ able inhibition was greater at $\mathrm{pH} 9$ (100\%inhibition) than at pH 6 (75\% inhibition).

Modification of the chemical structure of anandamide also provides potent inhibitors of FAAH. In 1998, arachidonoylserotonin was found to inhibit FAAH in either N18TG2 or RBL-2H3 cell membrane preparations. The compound was devoid of affinity for $\mathrm{CB}_{1}$ receptor, and did not behave as a cannabimimetic agent in mice, as demonstrated with the lack of response in the mouse tetrad test [146]. Arachidonoyldopamine and pinolenoyldopamine are potent inhibitors of FAAH, however they are potent ligands of the $\mathrm{CB}_{1}$ receptor with $\mathrm{Ki}$ values of 1 and $0,25 \mu \mathrm{M}$. They are also good ligands of the $\mathrm{CB}_{2}$ receptor, with $\mathrm{Ki}$ values of 11,3 and $12 \mu \mathrm{M}$. Arachidonoyldopamine was evaluated in vivo in the mouse tetrad test, and it acts as a cannabimimetic substance which induces analgesia, inhibits spontaneous activity in an open field, decreases rectal temperature and causes immobility on a ring [58].

In 2000, Boger synthesised 1-oxazolo [4, 5- $b$ ]pyridin-2yl eicosa-5Z, 8Z, 11Z, 14Z-tetraen-1-one, which inhibits FAAH with a Ki value of $1 \mathrm{nM}$ [147]. In 2002, van der Stelt reported the inhibition of FAAH by oxygenated metabolites of anandamide; enzymatically synthesised by soybean and barley lipoxygenases. 15(S)-hydroxy-eicosa-5Z, 8Z, 11Z, $13 E$-tetraenoyl- $N$-(2-hydroxyethyl)amine was found to inhibit FAAH with a $\mathrm{Ki}$ value of $0,63 \mu \mathrm{M}$, and to bind selectively to the $\mathrm{CB}_{1}$ receptor. $11(S)$-hydroxy-eicosa- $5 Z, 8 Z$, $12 E, 14 Z$-tetraenoyl- $N$-(2-hydroxyethyl)amine is characterised by a $\mathrm{Ki}$ value of $0,57 \mu \mathrm{M}$ and did not bind to either receptor [148].
As he did with arachidonoyl fatty acid chain, Boger synthesised oleoyl $\alpha$-keto heterocycle inhibitors. 1-oxazolo $[4,5-b]$ pyridin-2-yl-9Z-octadecen-1-one and its methylated derivative in position 2 are potent inhibitors of FAAH with $\mathrm{Ki}$ values of 2, 3 and 9, $1 \mathrm{nM}$, respectively [149]. The most potent inhibitor of the $\alpha$-keto heterocycle family is 1-oxazolo [4, 5-b] pyridin-2-yl-6-phenylhexan-1-one, characterised by a Ki value of $200 \mathrm{pM}$ on rat FAAH and $94 \mathrm{pM}$ on human FAAH [147]. However, the affinities of these compounds for the cannabinoid receptors were not investigated. Boger has also developed trifluoromethyl ketone inhibitors, which are not derivated of the structure of substrates of FAAH. 1, 1, 1trifluoro-8-(2-heptylphenyl)-2-octanone and 1, 1, 1-trifluoro9-phenyl-2-nonanone are potent inhibitors of FAAH with $\mathrm{Ki}$ values of 96 and $25 \mathrm{nM}$, respectively [150] (Table 2).

\section{COMPOUNDS WITH INHIBITORY POTENTIAL BUT NOT DESIGNED AS INHIBITORS OF FAAH}

Cannabidiol, cannabinol and $\Delta^{9}$ THC inhibit FAAH activity in mouse brain microsomes. In the presence of 58 $\mu \mathrm{M}$ of anandamide, the inhibitory potency decreased from cannabidiol (160 $\mu \mathrm{M}, 66 \%$ inhibition), cannabinol $(160 \mu \mathrm{M}$, $46 \%$ inhibition) to $\Delta^{9}$-THC $(160 \mu \mathrm{M}, 31 \%$ inhibition) [151154] These cannabinoids increase the $\mathrm{Km}$ value of FAAH without affecting Vmax, suggesting a competitive inhibition [155]. The non-steroidal anti-inflammatory drugs ibuprofen [108], [156], suprofen, ketorolac [108], flurbiprofen [156] and indomethacin [157] also produce inhibition of FAAH. The inhibitions caused by ibuprofen and ketorolac are slightly stereoselective, the $R$-isoforms of these compounds are more potent than the $S$-isoforms. In contrast, the $R$ - and $S$-isoforms of flurbiprofen have similar $\mathrm{IC}_{50}$ values. The general anaesthetic propofol is a competitive inhibitor of FAAH characterised by a $\mathrm{IC}_{50}$ value of $52 \mu \mathrm{M}$. Propofol does not bind to the $\mathrm{CB}_{1}$ receptor however, the $\mathrm{CB}_{1}$ receptor 


\section{Table 2. Other Inhibitors of FAAH}

\begin{tabular}{|c|c|c|c|c|c|c|}
\hline \multirow[b]{2}{*}{ Chemical structure } & \multirow{2}{*}{$\begin{array}{c}\text { Name } \\
\text { Mechanism of } \\
\text { inhibition }\end{array}$} & \multicolumn{2}{|c|}{ FAAH inhibition } & \multicolumn{2}{|c|}{ Affinity for $\mathbf{C B}_{1}$ receptor } & \multirow[b]{2}{*}{ References } \\
\hline & & $\begin{array}{c}\mathbf{K i} / \mathbf{I} \mathbf{C C}_{50} \\
\text { (assay pH) }\end{array}$ & $\begin{array}{c}\text { Radioligand used, } \\
\text { source of FAAH }\end{array}$ & $\mathbf{K i} / \mathbf{I C}_{\mathbf{5 0}}$ & $\begin{array}{c}\text { Radioligand } \\
\text { used, source of } \\
\text { CB1 receptor }\end{array}$ & \\
\hline & $\begin{array}{c}\text { arachidonoyl } \\
\text { trifluoromethyl } \\
\text { ketone (ATFMK) } \\
\text { transition-state } \\
\text { inhibitor }\end{array}$ & $\begin{array}{c}\mathrm{IC}_{50} 0,23 \mu \mathrm{M} \\
(\mathrm{pH} 7.6)[108] \\
\mathrm{IC}_{50} 3 \mu \mathrm{M}[99] \\
(\mathrm{pH} 7.4)\end{array}$ & $\begin{array}{c}{\left[{ }^{3} \mathrm{H}\right] \text {-AEA }} \\
\text { rat brain } \\
\text { homogenates [108] } \\
{\left[{ }^{14} \mathrm{C}\right]-\mathrm{AEA}} \\
\mathrm{N} 18 \mathrm{TG} 2 \text { cells } \\
\text { homogenates [99] }\end{array}$ & $\begin{array}{c}\text { Ki } 0,65 \\
\mu \mathrm{M}[140]\end{array}$ & $\begin{array}{c}{\left[{ }^{3} \mathrm{H}\right]-\mathrm{CP} 55940} \\
\text { rat brain } \\
\text { membranes } \\
{[140]}\end{array}$ & $\begin{array}{l}\text { Koutek [140] } \\
\text { Fowler [108] } \\
\text { Maurelli [99] }\end{array}$ \\
\hline & $\begin{array}{c}\begin{array}{c}\text { Oleoyltrifluoro- } \\
\text { methyl ketone }\end{array} \\
\text { Transition-state } \\
\text { inhibitor }\end{array}$ & $\begin{array}{c}\mathrm{Ki} 1,2 \mathrm{nM} \\
(\mathrm{pH} 10.0) \\
\\
\mathrm{Ki} 0,082 \mu \mathrm{M} \\
\mathrm{IC}_{50} 0,46 \mu \mathrm{M} \\
(\mathrm{pH} 9.0)\end{array}$ & $\begin{array}{c}\text { oleamide } \\
\text { rat liver plasma } \\
\text { membrane extracts } \\
{\left[{ }^{14} \mathrm{C}\right] \text {-oleamide }} \\
\text { rat liver plasma } \\
\text { membrane extracts }\end{array}$ & $\begin{array}{l}- \\
-\end{array}$ & - & $\begin{array}{c}\text { Patterson } \\
\text { [141] } \\
\text { Boger [150] }\end{array}$ \\
\hline & $\begin{array}{l}\text { Palmitoyl } \\
\text { isopropylamide } \\
\text { Mixed-type } \\
\text { inhibitor }\end{array}$ & $\begin{array}{c}\mathrm{IC}_{50} 12,8 \mu \mathrm{M} \\
(\mathrm{pH} 7.6)\end{array}$ & $\begin{array}{c}{\left[{ }^{3} \mathrm{H}\right] \text {-AEA }} \\
\text { rat brain } \\
\text { homogenates }\end{array}$ & $\begin{array}{c}\text { No binding at } \\
\text { concentration as } \\
\text { high as } 100 \mu \mathrm{M}\end{array}$ & $\begin{array}{c}{\left[{ }^{3} \mathrm{H}\right]-\mathrm{CP} 55940} \\
\mathrm{hCB}_{1} \text { transfected } \\
\text { CHO cells }\end{array}$ & Jonsson [142] \\
\hline $\mathrm{CH}_{3}\left(\mathrm{CH}_{2}\right)_{1}$ & $\begin{array}{c}N-(1-\text { oxohexadecyl }) \\
\text { glycine methyl ester } \\
\text { Mechanism not yet } \\
\text { elucidated }\end{array}$ & $\begin{array}{c}\mathrm{IC}_{50} 10 \mu \mathrm{M} \\
(\mathrm{pH} 7.6)\end{array}$ & $\begin{array}{c}\left.{ }^{3} \mathrm{H}\right]-\mathrm{AEA} \\
\text { rat brain } \\
\text { homogenates }\end{array}$ & $\begin{array}{c}\text { No binding at } \\
\text { concentration as } \\
\text { high as } 10 \mu \mathrm{M}\end{array}$ & $\begin{array}{c}{\left[{ }^{3} \mathrm{H}\right]-\mathrm{CP} 55940} \\
\mathrm{hCB}_{1} \text { transfected } \\
\text { CHO cells }\end{array}$ & $\begin{array}{c}\text { Vandevoorde } \\
{[144]}\end{array}$ \\
\hline $\mathrm{CH}_{3}\left(\mathrm{CH}_{2}\right)_{14} \mathrm{NH}$ & $\begin{array}{c}N \text {-(2-acetoxyacetyl) } \\
\text { pentadecylamine } \\
\text { Mechanism not yet } \\
\text { elucidated }\end{array}$ & $\begin{array}{c}\mathrm{IC}_{50} 8,3 \mu \mathrm{M} \\
(\mathrm{pH} 7.6)\end{array}$ & $\begin{array}{l}\left.{ }^{3} \mathrm{H}\right]-\mathrm{AEA} \\
\text { rat brain } \\
\text { homogenates }\end{array}$ & $\begin{array}{c}\text { No binding at } \\
\text { concentration as } \\
\text { high as } 10 \mu \mathrm{M}\end{array}$ & $\begin{array}{c}\left.{ }^{3} \mathrm{H}\right]-\mathrm{CP} 55940 \\
\mathrm{hCB}_{1} \text { transfected } \\
\text { CHO cells }\end{array}$ & $\begin{array}{c}\text { Vandevoorde } \\
{[144]}\end{array}$ \\
\hline & $\begin{array}{l}\text { Arachidonoyl- } \\
\text { serotonin } \\
\text { Non-covalent } \\
\text { inhibition }\end{array}$ & $\begin{array}{c}\mathrm{IC}_{50} 12 \mu \mathrm{M} \\
(\mathrm{pH} 9.0) \\
\mathrm{IC}_{50} 5,6 \mu \mathrm{M} \\
(\mathrm{pH} 9.0)\end{array}$ & $\begin{array}{c}{\left[{ }^{14} \mathrm{C}\right]-\mathrm{AEA}} \\
\mathrm{N} 18 \mathrm{TG} 2 \text { cell } \\
\text { membranes } \\
{\left[{ }^{14} \mathrm{C}\right]-\mathrm{AEA}} \\
\text { RBL-2H3 cell } \\
\text { membranes }\end{array}$ & $\begin{array}{c}\text { No binding at } \\
\text { concentration as } \\
\text { high as } 50 \mu \mathrm{M}\end{array}$ & $\begin{array}{c}{\left[{ }^{3} \mathrm{H}\right]-\mathrm{SR} 141716 \mathrm{~A}} \\
\mathrm{~N} 18 \mathrm{TG} 2 \text { cell } \\
\text { membranes }\end{array}$ & $\begin{array}{c}\text { Bisogno } \\
{[146]}\end{array}$ \\
\hline & $\begin{array}{l}\text { Arachidonoyl- } \\
\text { dopamine } \\
\text { competitive }\end{array}$ & $\begin{array}{l}\mathrm{IC}_{50} 22 \mu \mathrm{M} \\
\mathrm{IC}_{50} 23 \mu \mathrm{M}\end{array}$ & $\begin{array}{c}{\left[{ }^{14} \mathrm{C}\right]-\mathrm{AEA}} \\
\mathrm{N} 18 \mathrm{TG} 2 \text { cell } \\
\text { membranes } \\
{\left[{ }^{14} \mathrm{C}\right]-\mathrm{AEA}} \\
\text { RBL-2H3 cell } \\
\text { membranes }\end{array}$ & Ki $0,25 \mu \mathrm{M}$ & $\begin{array}{c}{\left[{ }^{3} \mathrm{H}\right]-\mathrm{SR}} \\
\text { 141716A rat brain } \\
\text { homogenates }\end{array}$ & Bisogno [58] \\
\hline & $\begin{array}{c}\text { Pinolenoyldopamine } \\
\text { Mechanism not yet } \\
\text { elucidated }\end{array}$ & $\mathrm{IC}_{50} 19 \mu \mathrm{M}$ & $\begin{array}{c}{\left[{ }^{14} \mathrm{C}\right]-\mathrm{AEA}} \\
\mathrm{N} 18 \mathrm{TG} 2 \text { cell } \\
\text { membranes }\end{array}$ & Ki $1,0 \mu \mathrm{M}$ & $\begin{array}{c}{\left[{ }^{3} \mathrm{H}\right]-\mathrm{SR}} \\
141716 \mathrm{~A} \text { rat brain } \\
\text { homogenates }\end{array}$ & Bisogno [58] \\
\hline & $\begin{array}{c}\text { 1-oxazolo[4,5- } \\
\text { b]pyridin-2-yl } \\
\text { eicosa-5Z,8Z, } \\
\text { 11Z,14Z-tetraen-1- } \\
\text { one (compound } \\
38 \text { of }[147]) \\
\text { Mechanism not yet } \\
\quad \text { elucidated }\end{array}$ & $\begin{array}{l}\mathrm{Ki} 1 \mathrm{nM} \\
(\mathrm{pH} 9.0)\end{array}$ & $\begin{array}{c}{\left[{ }^{14} \mathrm{C}\right] \text {-oleamide }} \\
\text { rat liver plasma } \\
\text { membrane } \\
\text { extracts }\end{array}$ & - & - & Boger [147] \\
\hline
\end{tabular}


(Table 2) contd....

\begin{tabular}{|c|c|c|c|c|c|c|}
\hline \multirow[b]{2}{*}{ Chemical structure } & \multirow{2}{*}{$\begin{array}{c}\text { Name } \\
\text { Mechanism of } \\
\text { inhibition }\end{array}$} & \multicolumn{2}{|c|}{ FAAH inhibition } & \multicolumn{2}{|c|}{ Affinity for $\mathbf{C B}_{1}$ receptor } & \multirow[b]{2}{*}{ References } \\
\hline & & $\begin{array}{c}\mathbf{K i} / \mathbf{I C}_{50} \\
\text { (assay } \mathbf{p H} \text { ) }\end{array}$ & $\begin{array}{c}\text { Radioligand used, } \\
\text { source of FAAH }\end{array}$ & $\mathbf{K i} / \mathbf{I C}_{\mathbf{5 0}}$ & $\begin{array}{c}\text { Radioligand } \\
\text { used, source of } \\
\text { CB1 receptor }\end{array}$ & \\
\hline & $\begin{array}{c}\text { 15(S)-hydroxy- } \\
\text { eicosa- } \\
5 Z, 8 Z, 1 Z, 13 E- \\
\text { tetraenoyl- } N \text { - }(2- \\
\text { hydroxyethyl) amine } \\
\text { Mechanism not yet } \\
\text { elucidated }\end{array}$ & $\begin{array}{c}\text { Ki } 0,63 \mu \mathrm{M} \\
(\mathrm{pH} 9.0)\end{array}$ & $\begin{array}{l}{\left[{ }^{3} \mathrm{H}\right] \text {-AEA }} \\
\text { U937 cells }\end{array}$ & Ki $600 \mathrm{nM}$ & $\begin{array}{c}{\left[{ }^{3} \mathrm{H}\right]-\mathrm{CP} 55940} \\
\text { rat brain } \\
\text { membranes }\end{array}$ & $\begin{array}{c}\text { Van der Stelt } \\
{[148]}\end{array}$ \\
\hline $\mathrm{HO}^{\circ}$ & $\begin{array}{c}\text { (11(S)-hydroxy- } \\
\text { eicosa- } \\
5 Z, 8 Z, 12 E, 14 Z- \\
\text { tetraenoyl- } N \text { - }(2- \\
\text { hydroxyethyl)amine } \\
\text { Mechanism not yet } \\
\text { elucidated }\end{array}$ & $\begin{array}{c}\text { Ki 0,57 } \mu \mathrm{M} \\
(\mathrm{pH} 9.0)\end{array}$ & $\begin{array}{l}{\left[{ }^{3} \mathrm{H}\right] \text {-AEA }} \\
\text { U937 cells }\end{array}$ & $\mathrm{Ki}>1000 \mathrm{nM}$ & $\begin{array}{c}{\left[{ }^{3} \mathrm{H}\right]-\mathrm{CP} 55940} \\
\text { rat brain } \\
\text { membranes }\end{array}$ & $\begin{array}{c}\text { Van der Stelt } \\
{[148]}\end{array}$ \\
\hline & $\begin{array}{c}\text { 1-oxazolo[4,5-b] } \\
\text { pyridin-2-yl-9Z- } \\
\text { octadecen-1-one } \\
\text { (compound } 3 \text { of } \\
{[149] \text { ) }} \\
\text { Mechanism not yet } \\
\text { elucidated }\end{array}$ & $\begin{array}{c}\text { Ki } 2,3 \mathrm{nM} \\
(\mathrm{pH} 9.0)\end{array}$ & $\begin{array}{l}{\left[{ }^{14} \mathrm{C}\right] \text {-oleamide }} \\
\text { rat liver plasma } \\
\text { membrane } \\
\text { extracts }\end{array}$ & - & - & Boger [149] \\
\hline & $\begin{array}{c}\text { 2-methyl-1- } \\
\text { oxazolo[4,5-b] } \\
\text { pyridin-2-yl-9Z- } \\
\text { octadecen-1-one } \\
\text { (compound } 15 \text { of } \\
{[149] \text { ) }} \\
\text { Mechanism not yet } \\
\text { elucidated }\end{array}$ & $\begin{array}{c}\text { Ki 9,1 nM } \\
(\mathrm{pH} 9.0)\end{array}$ & $\begin{array}{l}{\left[{ }^{14} \mathrm{C}\right] \text {-oleamide }} \\
\text { rat liver plasma } \\
\text { membrane } \\
\text { extracts }\end{array}$ & - & - & Boger [149] \\
\hline $\mathrm{O}$ & $\begin{array}{c}\text { 1-oxazolo[4,5-b] } \\
\text { pyridin-2-yl-6- } \\
\text { phenylhexan-1-one } \\
\text { (compound } 53 \text { of } \\
{[147] \text { ) }} \\
\text { Mechanism not yet } \\
\text { elucidated }\end{array}$ & $\begin{array}{l}\text { Ki } 200 \mathrm{pM} \\
\text { (pH 9.0) } \\
\\
\\
\text { Ki } 94 \mathrm{pM} \\
(\mathrm{pH} \mathrm{9.0)}\end{array}$ & $\begin{array}{c}{\left[{ }^{[4} \mathrm{C}\right] \text {-oleamide }} \\
\text { rat liver plasma } \\
\text { membrane e } \\
\text { xtracts } \\
\\
{\left[{ }^{14} \mathrm{C}\right] \text {-oleamide }} \\
\text { human FAAH } \\
\text { transfected } \\
\text { COS- } 7 \text { cells }\end{array}$ & - & - & Boger [147] \\
\hline & $\begin{array}{l}\text { 1,1,1-trifluoro-8-(4- } \\
\text { heptylphenyl)-2- } \\
\text { octanone } \\
\text { (compound } 13 \text { of } \\
{[150] \text { ) }} \\
\text { Mechanism not yet } \\
\text { elucidated }\end{array}$ & $\begin{array}{c}\mathrm{Ki} 96 \mathrm{nM} \\
\text { IC }_{50} 0,59 \mu \mathrm{M}\end{array}$ & $\begin{array}{l}{\left[{ }^{14} \mathrm{C}\right] \text {-oleamide }} \\
\text { rat liver plasma } \\
\text { membrane }\end{array}$ & - & - & Boger $[150]$ \\
\hline & $\begin{array}{c}\text { 1,1,1-trifluoro-9- } \\
\text { phenyl-2-nonanone } \\
\text { (compound } 21 \text { of } \\
{[150] \text { ) }} \\
\text { Mechanism not yet } \\
\text { elucidated }\end{array}$ & $\begin{array}{c}\mathrm{Ki} 25 \mathrm{nM} \\
\mathrm{IC}_{50} 0,12 \mu \mathrm{M}\end{array}$ & $\begin{array}{c}{\left[{ }^{14} \mathrm{C}\right] \text {-oleamide }} \\
\text { rat liver plasma } \\
\text { membrane }\end{array}$ & - & - & Boger [150] \\
\hline
\end{tabular}


antagonist SR141716A and the $\mathrm{CB}_{1}$ receptor agonist WIN $55,212-2$ significantly potentiate the loss of righting reflex produced by propofol. The intra peritoneal administration of propofol was also shown to increase the brain content of anandamide from $19 \mathrm{ng} / \mathrm{g}$ wet tissue to $23 \mathrm{ng} / \mathrm{g}$ wet tissue [158].

\section{FAAH ${ }^{(-/-)}$Mice}

In 2001, Cravatt reported the generation of $\mathrm{FAAH}^{(--)}$ mice, which possess enhanced endogenous cannabinoid levels and activity [201]. Brain and liver tissues from $\mathrm{FAAH}^{(--)}$mice hydrolyse anandamide and oleamide 50-100fold more slowly than brain extracts from $\mathrm{FAAH}^{(+/+)}$mice. Brain levels of anandamide are also enhanced in FAAH $^{(--)}$ mice, which present 15-fold higher levels of anandamide than brains from $\mathrm{FAAH}^{(+/+)}$mice. The responses of $\mathrm{FAAH}^{(-/)}$ and $\mathrm{FAAH}^{(++)}$mice to anandamide were compared in the tetrad test. In $\mathrm{FAAH}^{(--)}$mice, AEA produces behavioural responses at very low doses $(6.25-50 \mathrm{mg} / \mathrm{kg})$, which are totally inactive in $\mathrm{FAAH}^{(++)}$mice. Anandamide causes hypomotility, analgesia, catalepsy and hypothermia, which are blocked by pre-treatment with the $\mathrm{CB}_{1}$ receptor antagonist SR141716A. However, by $24 \mathrm{~h}$ post-treatment with anandamide, FAAH ${ }^{(-/-)}$are indistinguishable from the $\mathrm{FAAH}^{(+/+)}$ mice. FAAH $^{(-/)}$mice also exhibit reduced pain sensitivity, even in the absence of exogenous administration of a cannabinoid agent. They naturally exhibit a reduction in pain behaviour in the tail-immersion, hot plate and during the early phase of the formalin test. Furthermore, this naturally reduced pain sensitivity of $\mathrm{FAAH}^{(--)}$mice is completely inhibited by the administration of the $\mathrm{CB}_{1}$ receptor antagonist SR141716A. Very recently, it was reported that the
$\mathrm{FAAH}^{(--)}$mice exhibit a proconvulsant activity. Treatment of FAAH $^{(-/)}$mice with AEA significantly enhance the severity of bicuculline- or kainate- induced seizures, while AEA does not induce the same effect in $\mathrm{FAAH}^{(+/+)}$mice [160].

\section{MONOGLYCERIDE LIPASE}

\section{Molecular Structure}

In 1976, Tornqvist and Belfrage reported the purification of an enzyme responsible for the main monoacylglycerol hydrolysing activity of crude adipose rat tissue [161]. Enzymatic degradation of 2-AG was later demonstrated in porcine islets homogenate [162] and in circulating and tumoural macrophages [163]. In 1997, the cDNa cloning of the mouse monoglyceride lipase (MGL) was succeeded by Karlsson. The mouse amino acid sequence consists of 303 amino acids, corresponding to a molecular weight of 33, 218 daltons. The catalytic triad of this serine hydrolase was also identified to be consisted of Ser-122, Asp-239 and His-269, and was confirmed by site-mutagenesis experiments [164]. Five years later, the cDNA cloning of the rat MGL was completed by Dinh. The rat cDNA sequence encodes for a 303 amino acids protein with a molecular weight of 33, 367 daltons [78]. The human MGL cDNA was also cloned and shows $84 \%$ identity with the mouse MGL [165] and $85 \%$ identity with the rat MGL (Fig. 3). The residues identified to constitute the catalytic triad of mouse MGL were found to be conserved in human MGL.

\section{Distribution}

MGL is ubiquitously distributed in rat organs. Northern blot analysis confirmed the presence of MGL mRNA in

\begin{tabular}{|c|c|}
\hline Mouse & MPEASSPRRTPQNVPYQDLPHLVNADGQYLFCRYWKPSGTPKALIFVSHGAGEHCGRYDE 60 \\
\hline Rat & MPEASSPRRTPQNVPYQDLPHLVNADGQYLFCRYWKPSGTPKALIFVSHGAGEHCGRYDE \\
\hline Human & MPEESSPRRTPQS I PYQDLPHLVNADGQYLFCRYWKPTGTPKALIFVSHGAGEHSGRYE E \\
\hline Mouse & LAHMLKGLDMLVFAHDHVGHGQSEGERMVVSDFQVFVRDVLQHVDTI QKDYPDVPI FLLG 120 \\
\hline Rat & LAQMLKRLDMLVFAHDHVGHGQSEGERMVVSDFQVFVRDL LQHVNTVQKDYPEVPVFLLG \\
\hline Human & LARMLMGLDLLVFAHDHVGHGQSEGERMVVSDFHVFVRDV LQHVDSMQKDYPGLPVFLLG \\
\hline Mouse & HSMGGAIS ILVAAERPTYFSGMVLISPLVLANPESASTLKVLAAKLLNFVLPNMTLGRID 180 \\
\hline Rat & HSMGGAIS ILAAAERPTHFSGM I LISPLI LANPESAS TLKVLAAKLLNFVLPNI S LGRID \\
\hline Human & HSMGGAIAILTAAERPGHFAGMVLISPLVLANPESATTFKVLAAKVLNLVLPNLSLGPID \\
\hline Mouse & SSVLSRNKSEVDLYNSDPLVCRAGLKVCFGIQLLNAVARVERAMPRLTLPFLLLQGSADR 240 \\
\hline Rat & SSVLSRNKSEVDLYNSDPLI CHAGVKVCFGIQLLNAVS RVERAMPRLTLPFLLLQGSADR \\
\hline Human & SSVLSRNKTEVDIYNSDPL I CRAGLKVCFGIQLLNAVS RVERAL PKLTVPFLLLQGSADR \\
\hline Mouse & LCDSKGAYLLMES S RSQDKTLKMYEGAYHVLHRELPEVTNSVLHEVNSWVSH RIAAAGAG 300 \\
\hline Rat & LCDSKGAYLLMES S PSQDKTLKMYEGAYHVLHK ELPEVTNSVLHEINTWVSH RI AVAGAR \\
\hline Human & LCDSKGAYLLMELAKSQDKTLK I YEGAYHULHK ELPEVTNSVFHEI NMWVSQRTATAGTA \\
\hline Mouse & CPP \\
\hline Rat & CLP 303 \\
\hline Human & \\
\hline
\end{tabular}

Fig. (3). Amino acid sequence alignment between mouse, rat and human MGL. Identical amino acids are shaded in gray. The residues constituting the catalytic triad are boxed. 
adipose tissue, adrenal gland, heart, brain, kidney, testis, ovary, spleen, lung, liver and skeletal muscle [164]. In situ hybridisation revealed that MGL mRNA is heterogeneously expressed in the rat brain, with highest levels in regions where $\mathrm{CB}_{1}$ receptors are also present (hippocampus, cortex, anterior thalamus and cerebellum) [78].

\section{Assays}

To investigate the nature of the substrates hydrolysed by MGL, Dinh et al. have overexpressed MGL in HeLa cells by adenoviral vector-mediated gene transfer [78]. This method confers high levels of MGL immunoreactivity to these cells, which normally do not express MGL. They incubated supernatant protein in sodium phosphate buffer $(50 \mathrm{mM}, \mathrm{pH}$ 8.0) with 2-oleoyl- $\left[{ }^{3} \mathrm{H}\right]$-glycerol or $2-\left[{ }^{3} \mathrm{H}\right]$-AG as substrates. The reaction products were separated by organic solvent extraction (chloroform:methanol, 1:1). When 2-oleoyl- $\left[{ }^{3} \mathrm{H}\right]-$ glycerol was used, the released $\left[{ }^{3} \mathrm{H}\right]$-glycerol in the aqueous phase was counted by scintillation counting. When $2-\left[{ }^{3} \mathrm{H}\right]-$ AG was used, the organic phase was subjected to a further TLC purification.

\section{Substrates}

Dinh et al. found that MGL was capable of hydrolysing 2-AG and 2-oleoyl-glycerol, a result, which was earlier reported by Tornqvist on a purified enzyme from rat adipose tissue [161]. The question of the possible hydrolysis of AEA by MGL was particularly relevant, since FAAH hydrolyses AEA and 2-AG in vitro [112]. Goparaju even reported that the hydrolysis of 2-AG by FAAH proceeds about 4-fold faster than the anandamide hydrolysis [112]. However, several observations indicated that the hydrolysis of 2-AG proceeds by another enzyme, different of FAAH. A rapid degradation of 2-AG was observed in mouse blood, under the conditions where anandamide is stable [166]. The FAAH $^{(-)}$which is characterised by a total loss of AEA hydrolysing activity, preserves its capacity to hydrolyse 2AG [167]. However, MGL and FAAH are different in terms of substrate specificity and MGL preferentially hydrolyses 2monoglycerides but not fatty acid ethanolamides such as AEA and PEA [78].

\section{Inhibitors}

MGL activity is inhibited by various serine hydrolase inhibitors that were previously shown to block FAAH. Interestingly, the $\mathrm{IC}_{50}$ values observed are higher for the inhibition of MGL hydrolysis than those obtained for inhibition of FAAH hydrolysis. Indeed, arachidonoylfluorophosphonate(MAFP), arachidonoyl trifluoromethylketone (ATFMK) and hexadecylsulfonylfluoride(AM374) are characterised by $\mathrm{IC}_{50}$ values for FAAH of $3 \mathrm{nM}, 0,23 \mu \mathrm{M}$ and $10,2 \mathrm{nM}$ and $\mathrm{IC}_{50}$ values for MGL of $0,8 \mu \mathrm{M}, 2,5 \mu \mathrm{M}$ and 6, $2 \mu \mathrm{M}$ [159], respectively.

In 1998, Ben-Shabat reported the coexistence, in the spleen, brain and gut, of 2-AG and several inactive endogenous fatty acid glycerol esters, like 2-linoleoylglycerol and 2-palmitoylglycerol. These esters are devoid of affinity for the $\mathrm{CB}$ receptors, however they significantly potentiate the $\mathrm{CB}$ binding, immobility, analgesia and hypothermia caused by $2-A G$ in mice. These compounds were described as responsible of an "entourage effect" capable of regulating the 2-AG cannabinoid activity. The inhibitory potential of the two esters on 2-AG hydrolysis was tested using mouse neuroblastoma N18TG2 and rat basophilic leukaemia cells, previously shown to contain enzymatic activities for catalysing 2-AG hydrolysis to arachidonic acid. 2-linoleoylglycerol but not 2-palmitoylglycerol, was shown to inhibit the enzymatic degradation of 2-AG in these cell lines [63]. However, the enzyme responsible of the degradation of 2AG in these cell lines rather appears to be FAAH since the hydrolysis of 2-AG was inhibited by AEA [168].

\section{N-PALMITOYLETHANOLAMINE-SELECTIVE ACID AMIDASE}

\section{Distribution-Substrates}

In 1999, Ueda et al. discovered a new hydrolase, distinguishable from FAAH, in human megakaryoblastic cell line (CMK). This enzyme was present in the $12000 \mathrm{X}$ g pellet of the CMK cell homogenate and was solubilised by freezethaw. PEA was the most active substrate for this solubilised enzyme, which was christened " $N$-palmitoylethanolamine selective acid amidase" or "NPAA". This enzyme was characterised by a molecular weight of $31 \mathrm{kDa}$, an optimal acidic $\mathrm{pH}$ of 5 [79] and it was activated by triton X-100. Two years later, the same group succeeded the isolation of NPAA from different rat tissues. The higher activity was found in the lung, spleen, small intestine, thymus, caecum and in peritoneal and alveolar macrophages. Lower activity was detected in the brain, submaxillary gland, heart, stomach, liver, large intestine, kidney and testis [169]. Very recently, NPAA activity was detected in the cytosol of RBL-1 cells whereas FAAH activity was found in the particulate fraction of these cells [170].

The purified NPAA lung enzyme was allowed to react with various $N$-acylethanolamides. PEA was found to be the most active substrate followed by $N$-myristoylethanolamide (C14:0), $N$-stearoylethanolamide(C18:0), N-oleoylethanolamide(C18:1), $N$-linoleoylethanolamide(C18:2) and finally AEA, which was poorly hydrolysed by NPAA [76].

\section{Assays}

Ueda et al. developed a NPAA assay in which the 12000 $\mathrm{X} g$ pellet of rat lung homogenates are incubated in presence of $\left[{ }^{14} \mathrm{C}\right]-\mathrm{PEA}$ in a citrate-sodium phosphate buffer ( $\mathrm{pH}$ 5.0) containing DTT and Triton X-100. The reaction is terminated by addition of a mixture of diethyl ether/methanol/ citric acid and the ethereal extracts are separated on a silica gel sheet eluated with a mixture of chloroform/methanol/ $28 \%$ ammonium hydroxide before counting of the radioactivity [170].

\section{Inhibitors}

NPAA is almost insensitive to PMSF and MAFP, two potent inhibitors of FAAH. Because PEA is the most active substrate of NPAA, derivatives of palmitic acid including esters, amides, retroesters and retroamides have been investigated as NPAA inhibitors. This has allowed the discovery of cyclohexylpalmitate and $\mathrm{N}$-(3-hydroxypropionyl)-pentadecanamide (Fig. 4). These compounds induce 

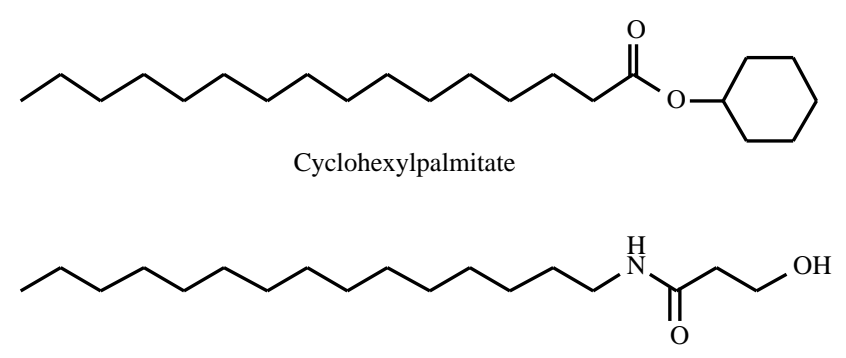

N-(3-hydroxypropionyl)-pentadecanamide

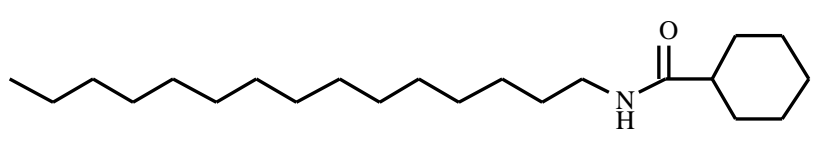

Cyclohexanecarbonylpentadecylamine

Fig. (4). Structures of cyclohexylpalmitate, $N$-(3-hydroxypropionyl)-pentadecanamide and $N$-cyclohexanecarbonylpentadecylamine, three inhibitors of NPAA.

84 and $77 \%$ inhibition of NPAA at $100 \mu \mathrm{M}$ (in presence of $\left.100 \mu \mathrm{M}\left[{ }^{14} \mathrm{C}\right]-\mathrm{PEA}\right)$ and they are characterised by $\mathrm{IC}_{50}$ values of 19 and $31 \mu \mathrm{M}$, respectively. Moreover, they are devoid of $\mathrm{CB}_{1}$ and $\mathrm{CB}_{2}$ affinity and they do not alter FAAH activity [171]. $N$-cyclohexanecarbonylpentadecylamine (Fig. 4) is a more potent inhibitor, which causes $95 \%$ inhibition of NPAA and is characterised by a $\mathrm{IC}_{50}$ value of $4.5 \mu \mathrm{M}$. The selectivity of the compound for NPAA has allowed its use as a tool to distinguish NPAA from FAAH, in RBL-1 cells [170].

\section{UPTAKE PROCESS: A NECESSARY STEP OF THE ENDOCANNABINOIDS DEGRADATION}

If FAAH, MGL and NPAA are the subject of a growing interest which has allowed an extensive characterisation and an in-depth knowledge of these three enzymes, less is known however about the way taken by their substrates, the endocannabinoids, to reach their catalytic sites. In this review, our intention is not to make an extensive description of the endocannabinoids transporters. This subject was already covered by four recent reviews of Hillard [172, 173], Giuffrida [174] and Fowler [175]. However, the quest for inhibitors of the endocannabinoids metabolism could not be carried out without considering their cellular transport to the catalytic sites of the enzymes responsible of their degradation. We propose to highlight the different observations, which prove or, on the contrary, invalidate the existence of endocannabinoids transporters. We also consider interesting to list the developed inhibitors of this major, but not yet cloned, putative uptake protein.

\section{Anandamide Uptake}

In 1994, Di Marzo et al. published the first report of a saturable and temperature-sensitive uptake of AEA with the characteristics of a facilitated diffusion. This first cellular transport of AEA was observed in cortical granule neurons and was rapidly followed by the hydrolysis of AEA by FAAH [176]. Three years later, Hillard et al. reported a time$\left(\mathrm{t}_{1 / 2}=2.6 \mathrm{~min}\right.$ at $\left.37^{\circ} \mathrm{C}\right)$ and temperature-dependent accumu- lation of AEA in cerebellar granule cells. This accumulation was saturable and characterised by an apparent $K_{m}$ of $41 \mu \mathrm{M}$ and a $V_{\max }$ value of $0.61 \mathrm{nmol} / \mathrm{min} / 10^{6}$ cells and was shown to be independent of sodium gradient and ATP. The observed accumulation was selective for AEA: only oleoylethanolamide was able to inhibit the cellular accumulation of AEA, at high concentration, while palmitoylethanolamide and linolenoylethanolamide were inactive [177]. Other investigators also demonstrated the existence of an AEA uptake process in cortical astrocytes [178], C6 glioma cells [74], N18TG2 neuroblastoma cell lines [74], CHP100 cells [102], human astrocytoma CCF-STTG1 cell line [179] and endothelial cells [180].

In 2000, Rakhshan et al. investigated the hypothesis that the uptake process in peripheral cells could be similar to that previously observed in the central nervous system. They showes that the mast cell line RBL-2H3 also exhibited a time- $\left(\mathrm{t}_{1 / 2}=3.2 \mathrm{~min}\right.$ at $\left.37^{\circ} \mathrm{C}\right)$ and temperature-dependent accumulation of AEA. This accumulation was saturable and characterised by an apparent $\mathrm{K}_{\mathrm{m}}$ of $11.4 \mu \mathrm{M}$ and a $\mathrm{V}_{\max }$ value of $0.17 \mathrm{nmol} / \mathrm{min} / 10^{6}$ cells and was shown to be independent of $\mathrm{Na}^{+}, \mathrm{Cl}^{-}$and $\mathrm{H}^{+}$gradients. Uptake process in RBL-2H3 cells was essentially selective for AEA: palmitoylethanolamide, ethanolamine, stearic acid and maleic acid were unable to inhibit the AEA accumulation in these cells. Interestingly, 2-AG, arachidonic acid and oleic acid elicitated a dose-dependent decrease in anandamide uptake in RBL-2H3 cells [181]. Cellular accumulation of AEA was also found to occur in J774 macrophages [99] and lymphoma U937 cell line [102]. However, it must be mentioned that all these cells do not accumulate AEA to the same degree. The uptake of AEA was the most effective in lymphoma U937 cell line and the lowest in human astrocytoma CCF-STTG1 cell line.

The mechanism of AEA cellular transport remains to be elucidated, however, the lack of dependence of ATP and sodium gradient suggest that AEA uptake is driven by diffusion and does not require energy. In 2000, Maccarrone et al. [180] reported the stimulation of AEA uptake in human 
Table 3. Compounds with Inhibitory Potential but not Designed as Inhibitors of FAAH

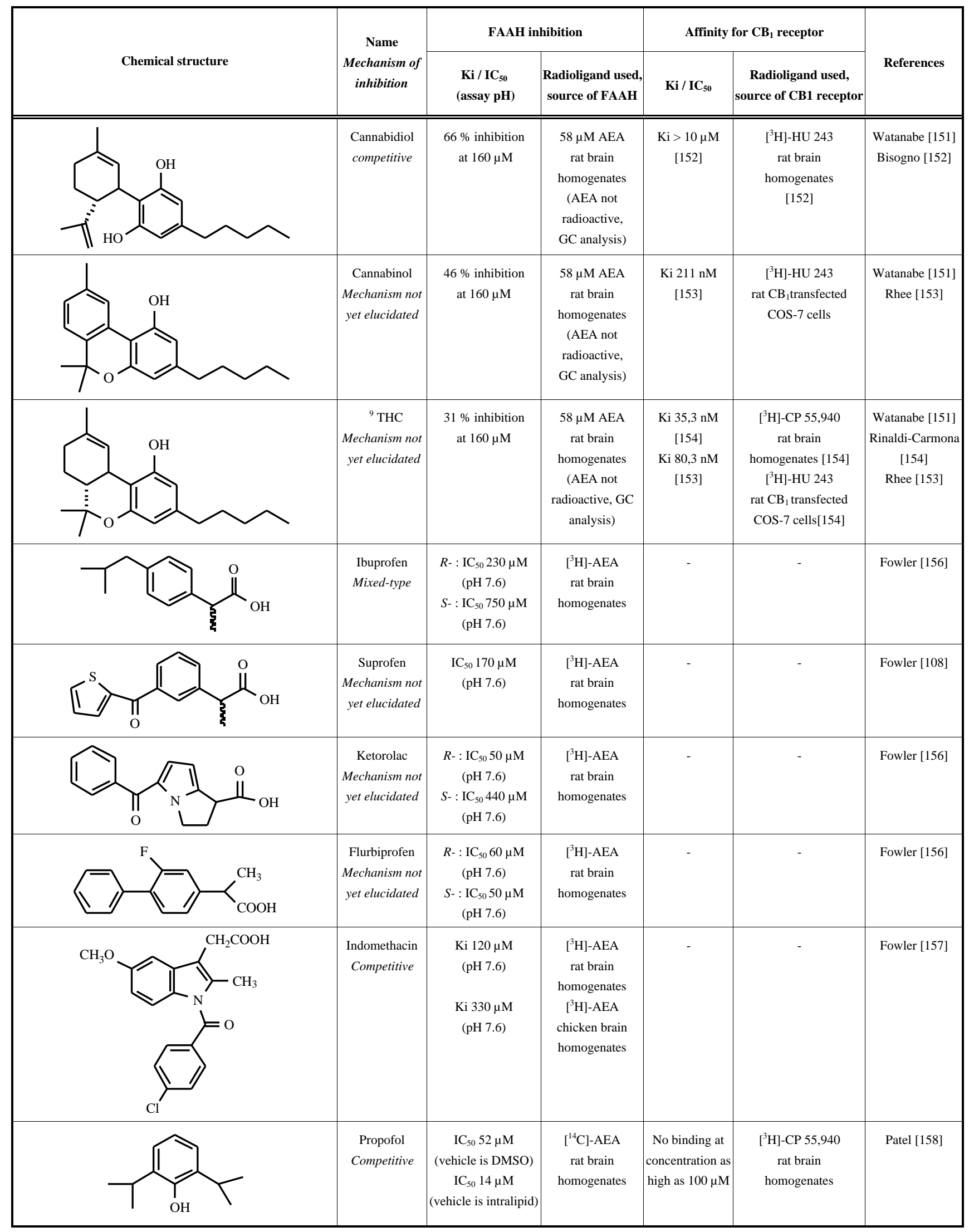


umbelical vein endothelial cells (HUVECs) by sodium nitroprusside, $S$-nitroso- $N$-acetylpenicillamine and spermine NONOate ((Z)-1- $\{N$ - [3-aminopropyl]- $N$ - [4-(3-aminopropylammonio)-butyl]-amino\}-diazen-1-ium-1, 2-diolate), three nitric oxide donors. Their results suggested that anandamide uptake in HUVECs is regulated by nitric oxide. Hillard et al. reported that cerebellar granule cells preloaded with $\left[{ }^{3} \mathrm{H}\right]-$ AEA exhibit a time- and temperature-dependent AEA efflux [172]. This observation was consistent with a protein carrier capable of moving AEA in both directions across the membrane, depending on the AEA concentration gradient across the membrane. Surprising is the finding that AEA concentrations on both sides of the cell are not equal when the AEA accumulation in cerebellar granule cells reaches a steady stade [172]. This observation suggests that only a part of AEA accumulated in the cell is intact and free to equilibrate with the extracellular AEA. Many biological actors are conceivable to explain this difference: FAAH could regulate the amounts of intact AEA in the cell, or some membranous compartments or intracellular proteins could reduce the amounts of free AEA in the cell after sequestration or binding.

In 2001, Day et al. and Deutsch et al. demonstrated the important role of FAAH in the cellular uptake of AEA. The accumulation of AEA was reported in RBL-2H3 [182], N18TG2 [183] and C6 [142] cell lines, which natively express FAAH. Similarly, FAAH-HeLa [182] and FAAHHep2 [183] transfected cells exhibit an AEA uptake 2-fold greater than in untransfected cells that lack FAAH. MAFP, a FAAH inhibitor structurally related to AEA, partially reduces the AEA accumulation in RBL-2H3, N18TG2 and C6 cell lines, but also in wild-type HeLa cells. Interestingly, MAFP does not inhibit the AEA uptake in wild-type Hep2 cells that lack FAAH [183] nor in cortical neurons, which exhibit FAAH activity [35]. Taken together, these results suggest that FAAH-transfection to a cell enhances the uptake of AEA however; complete inhibition of FAAH only results in partial AEA uptake inhibition. These observations support a partial, but not indispensable, role of FAAH in AEA uptake process.

In their last review [173], Hillard and Jarrahian published an elegant discussion about a possible reversible binding of AEA to an intracellular site which could have the characteristics of a carrier in terms of saturability and inhibition by structurally related molecules. Moreover, the existence of an AEA transporter was recently called into question by Glaser et al. who performed a study at initial rates of AEA accumulation in N18TG2 neuroblastoma and CCF-STTG1 astrocytoma cell lines. In these conditions, they demonstrated that AEA uptake was not saturable and that AM404 $(N$-(4-hydroxyphenyl) arachidonylamide) did not inhibit it. However, they used a procedure quite different of the other searchers teams by adding bovine serum albumin in the medium of the uptake assay. The presence of bovine serum albumin could induce major modifications in the transport of AEA in aqueous compartments by binding to AEA [184]. Very recently, Fasia et al. reported AEA accumulation in rabbit platelets, in contrast to human platelets [186], was not saturable and not temperature-dependent. Moreover, they demonstrated that PMSF and ATFMK, two FAAH inhibitors, had no effect and they concluded that AEA accumulation in rabbit platelets occurs by simple diffusion [186].

\section{Inhibitors of Anandamide Uptake}

We have previously shown that modifications of the chemical structure of substrates of FAAH have allowed the discovery of potent inhibitors of this enzyme. The same strategy was helpful for the design of inhibitors of AEA uptake. However, it is difficult, by this way, to synthesise selective inhibitors of AEA uptake, without any activity against FAAH. $N$-(4-hydroxyphenyl)-arachidonamide (AM404), a compound devoid of $\mathrm{CB}_{1}$ affinity [178], is a

Table 4. Summary of the Available Data on Fatty Acid Amide Hydrolase (FAAH), Monoglyceride Lipase (MGL) and $N$ Palmitoylethanolamine-Selective Amidase (NPAA)

\begin{tabular}{|c|c|c|c|}
\hline & FAAH & MGL & NPAA \\
\hline Localisation & brain, testis, uterus, kidney, liver & ubiquitous & $\begin{array}{l}\text { lung, spleen, } \\
\text { small intestine, thymus }\end{array}$ \\
\hline Cloned? & $\begin{array}{c}\text { Yes } \\
\text { human, rat, mouse, pig }\end{array}$ & $\begin{array}{c}\text { Yes } \\
\text { human, rat, mouse }\end{array}$ & no \\
\hline Optimal pH & $8.5-10$ & 8 & 5 \\
\hline Substrates & $\begin{array}{c}\text { AEA, } \\
N \text {-oleoylethanolamine }\end{array}$ & $\begin{array}{c}\text { 2-AG, } \\
\text { 2-oleoylglycerol }\end{array}$ & $\begin{array}{c}\text { PEA, } \\
N \text {-myristoylethanolamine, } \\
N \text {-stearoylethanolamine }\end{array}$ \\
\hline Potent inhibitors & $\begin{array}{c}\text { 1-oxazolo[4,5-b]pyridin-2-yl-6- } \\
\text { phenylhexan-1-one } \\
\text { ATFMK } \\
\text { MAFP }\end{array}$ & $\begin{array}{l}\text { ATFMK, } \\
\text { MAFP, } \\
\text { AM374 }\end{array}$ & $\begin{array}{l}\text { Cyclohexylpalmitate, } \\
N \text {-(3-hydroxypropionyl) } \\
\text { pentadecanamide, } \\
\text { cyclohexanecarbonyl- } \\
\text { pentadecylamine }\end{array}$ \\
\hline Knock-out & yes & no & no \\
\hline
\end{tabular}


potent inhibitor of AEA accumulation in rat neurons [177], cerebellar granule cells [187] and human CCF-STTG1 astrocytoma cells [178]. However, AM 404 inhibits FAAH activity in rat forebrain membranes [187] and N18TG2 cells [188] with $\mathrm{IC}_{50}$ values of 0,5 and $22 \mu \mathrm{M}$, respectively. It was also reported that AM404 elevates intracellular $\mathrm{Ca}^{2+}$ in Madin Darby canine kidney (MDCK), Chang liver, PC3 human prostate cancer, BFTC human bladder cancer and MG63 human osteoblast-like cells at a lower concentration than those commonly used to block AEA uptake [189]. This finding raised the question of the real selectivity of this compound and that caution must be exercised when this compound is used as a selective pharmacological tool to investigate the AEA transporter. In vivo, AM404 was shown to potentiate the hypotensive effects of AEA in anaesthesized guinea pigs [190]. N-(2-hydroxyphenyl)-arachidonamide, the ortho analogue of AM 404, is a less potent inhibitor of uptake than AM 404 [187]. Nevertheless, the suppression of the phenolic ring to afford arachidonamide maintains a moderate inhibition of AEA uptake, characterised by a $\mathrm{IC}_{50}$ value of $9 \mu \mathrm{M}$ [179]. VDM 11, a methylated derivative of AM404, is a very selective inhibitor of AEA uptake in RBL-2H3 and C6 glioma cells. VDM 11 is devoid of vanilloid and $\mathrm{CB}_{1}$ receptors affinity and does not exhibit inhibitory potential against FAAH [188]. AEA accumulation in RBL-2H3 and C6 glioma cells is also reduced by the two potent vanilloid agonists arvanil and olvanil [188] which do not inhibit FAAH [191, 192] but also exhibit moderate affinity for the $\mathrm{CB}_{1}$ receptor $[191,193]$.

In 2001, López-Rodríguez et al. reported the synthesis of $\mathrm{N}$-(3-furylmethyl) arachidonamide (UCM 707), the most potent and selective AEA transporter inhibitor described to date [194]. This compound inhibits AEA accumulation in human lymphoma U937 cells with an $\mathrm{IC}_{50}$ value of $0,8 \mu \mathrm{M}$. UCM 707 is totally devoid of affinity for the vanilloid $(\mathrm{Ki}>$ $5 \mu \mathrm{M})$ and $\mathrm{CB}_{1}$ receptors $(\mathrm{Ki}=4,7 \mu \mathrm{M})$, and does not inhibit FAAH $[195,196]\left(\mathrm{IC}_{50}\right.$ of $\left.30 \mu \mathrm{M}\right)$. However, UCM 707 exhibits remarkable affinity for $\mathrm{CB}_{2}$ receptor $(\mathrm{Ki}=67$ $\mathrm{nM})$. UCM 707 was evaluated in vivo in the open-field and hot-plate test. The compound was mostly inactive when administrated alone, but it was able to potentiate the hypokinetic and antinociceptive effects of AEA [197]. In 2003, Ortar et al. synthesised OMDM-1, a derivative of oleoylethanolamide which inhibit AEA accumulation in RBL-2H3 cells with a $\mathrm{Ki}$ of $2,4 \mu \mathrm{M}$. This compound was inactive as $\mathrm{CB}_{1}(\mathrm{Ki} 12,1 \mu \mathrm{M})$ and vanilloid $\left(\mathrm{EC}_{50}>10 \mu \mathrm{M}\right)$ ligand, as well as on FAAH $(\mathrm{Ki}>50 \mu \mathrm{M})$ [198].

As we have shown, most of the uptake inhibitors are derived from the structures either of AEA, or of oleoylethanolamide. We investigated the ability of derivatives of palmitoylethanolamide to inhibit AEA uptake in RBL-2H3 and C6 glioma cells. We found that palmitoylcyclohexamide induces a moderate inhibition of AEA uptake with no effect on FAAH and on cannabinoid receptors [142]. This result suggests that palmitoylcyclohexamide may act as a template for the design of potent and selective inhibitors of AEA accumulation. Endogenous compounds can also act as AEA uptake inhibitors: it was reported that glutamate and glutamine inhibit AEA uptake in human, rat and mouse synaptosomes by a non-competitive manner [199].

\section{Palmitoylethanolamide Uptake}

In 1997, Bisogno et al. published the first report on a saturable and temperature-dependent uptake of PEA and AEA in $\mathrm{J} 774$ macrophages and RBL-2H3 cells. The uptake of the two compounds in these cell lines was followed by hydrolysis. Because high concentrations of PEA and AEA were unable to inhibit the accumulation of, respectively, AEA and PEA, the existence of distinct uptake processes was suggested by the authors [100]. In 2001, Jacobsson and Fowler reported that a saturable and temperature-dependent facilitated transport of PEA, distinguishable from AEA uptake, occurs in Neuro-2a and RBL-2H3 cells [200]. In the same cell line, PEA uptake was characterised by higher apparent $\mathrm{Km}$ values than AEA uptake: apparent $\mathrm{Km}$ values were 10 (Neuro-2a) and $9.3 \mu \mathrm{M}$ (RBL-2H3) for AEA uptake, and 28 (Neuro-2a) and $30 \mu \mathrm{M}$ (RBL-2H3) for PEA uptake. Differences were also picked out in the inhibitors of these processes. AEA uptake in both cell lines was inhibited by AM404, 2-AG, methanandamide, arachidonic acid, olvanil and indomethacin but not by PEA. PEA uptake was inhibited by AEA, 2-AG, arachidonic acid, $\Delta^{9}$-THC, cannabidiol but not by indomethacin. Moreover, Rl-methanandamide only blocked PEA uptake in RBL-2H3, but not in Neuro-2a.

\section{2-Arachidonoylglycerol Uptake}

In 1998, Di Marzo et al. reported the first observation of a diffusion of 2-AG into RBL-2H3 and N18TG2 cells, with no evidence for a facilitated-diffusion process [168]. One year later, they demonstrated that $\left[{ }^{3} \mathrm{H}\right]-2-\mathrm{AG}$ is accumulated in $\mathrm{J} 774$ macrophages and they recovered the radioactivity in esterified $\left[{ }^{3} \mathrm{H}\right]-2-A G$ to phospholipids, diacylglycerols and triglycerides [164]. Beltramo and Piomelli confirmed this observation in CCF-STTG1 astrocytoma cell line in which 2$\mathrm{AG}$ is accumulated through a sodium and energy-independent process [201]. As it was reported in J774 macrophages, 2-AG is accumulated in CCF-STTG1 in an esterified form, as phospholipids, diacylglycerols and triacylglycerol, but also as free fatty acid (arachidonate) and unmetabolised 2AG. However, the 2-AG uptake in CCF-STTG1 cells was inhibited by anandamide and AM 404, suggesting that 2-AG is uptaken by the same transporter than AEA. In 2001, Bisogno et al. studied simultaneously the facilitated transport of AEA and 2-AG in C6 glioma cells [202]. They found that the AEA and 2-AG uptake mechanisms in these cells are characterised by similar $\mathrm{Km}$ values $(\mathrm{Km} 11$ and $15 \mu \mathrm{M}$, respectively) and different Bmax values (Bmax 1.70 and 0.24 , respectively). AEA uptake in C6 cells was inhibited by 2-AG at high concentration (Ki $30 \mu \mathrm{M})$ while 2-AG uptake was inhibited by either 2-AG (Ki $19 \mu \mathrm{M}$ ) and AEA (Ki 20 $\mu \mathrm{M})$. AM 404 inhibited either AEA or 2-AG uptake (Ki 7.5 and $10 \mu \mathrm{M}$, respectively). Sodium nitroprusside, $S$-nitroso$\mathrm{N}$-acetylpennicilamine and 3-morpholino-sydnonimine, three NO donors, slightly enhanced AEA and 2-AG uptake (approximatively $115 \%$ of control). These data suggested the existence of a 2-AG transporter, distinct from the AEA transporter, which shares similar molecular and regulatory features with the AEA transporter. During the same year, Maccarone et al. demonstrated the existence of a specific 2AG transporter in human platelets [203]. They demonstrated 
Table 5. Inhibitors of Anandamide Uptake

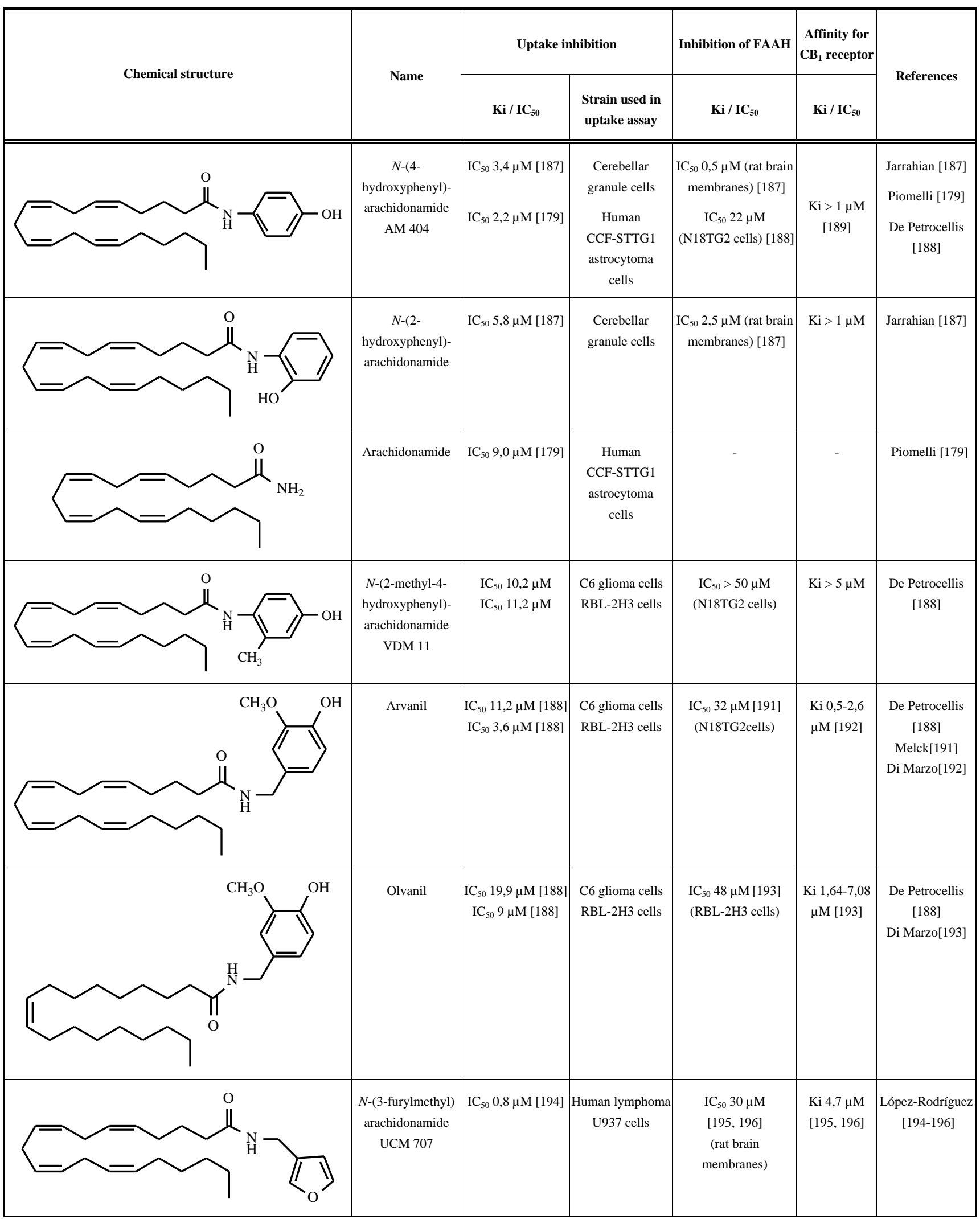


(Table 5) contd....

\begin{tabular}{|c|c|c|c|c|c|c|}
\hline \multirow{2}{*}{ Chemical structure } & \multirow{2}{*}{ Name } & \multicolumn{2}{|c|}{ Uptake inhibition } & \multirow{2}{*}{$\begin{array}{c}\text { Inhibition of FAAH } \\
\mathrm{Ki} / \mathrm{IC}_{50}\end{array}$} & \multirow{2}{*}{\begin{tabular}{|c|}
$\begin{array}{c}\text { Affinity for } \\
\mathbf{C B}_{1} \text { receptor }\end{array}$ \\
$\mathrm{Ki} / \mathrm{IC}_{50}$ \\
\end{tabular}} & \multirow{2}{*}{ References } \\
\hline & & $\mathrm{Ki} / \mathrm{IC}_{50}$ & $\begin{array}{l}\text { Strain used in } \\
\text { uptake assay }\end{array}$ & & & \\
\hline & OMDM-1 & Ki $2,4 \mu \mathrm{M}$ & RBL-2H3 cells & $\begin{array}{c}\mathrm{Ki}>50 \mu \mathrm{M} \text { (rat } \\
\text { brain homogenates) }\end{array}$ & $\mathrm{Ki} 12,1 \mu \mathrm{M}$ & Ortar [198] \\
\hline $\mathrm{O}$ & $\begin{array}{l}\text { Palmitoyl- } \\
\text { cyclohexamide }\end{array}$ & $\begin{array}{c}\text { AEA uptake } \\
\text { reduced to } 76 \%\end{array}$ & $\begin{array}{l}\text { C6 glioma } \\
\text { cells }\end{array}$ & $\begin{array}{l}\text { No inhibition } \\
\text { at } 100 \mu \mathrm{M}\end{array}$ & $\begin{array}{c}\text { No binding as } \\
\text { concentration } \\
\text { as high as } \\
100 \mu \mathrm{M}\end{array}$ & Jonsson [142] \\
\hline
\end{tabular}

that human platelets accumulate 2-AG through a transporter (Km $300 \mathrm{nM}$ ). Since AEA and AM404 did not inhibit 2-AG uptake, these results suggest that 2-AG is uptaken in platelets through a transporter distinguishable of the AEA transporter.

\section{CONCLUSION}

It is now established that the endocannabinoids have, by their actions on the cannabinoid receptors, a number of interesting pharmacological properties including antinociception, modulation of feeding, neuroprotection and antiproliferative effect. However, their therapeutic use is strongly prevented by their rapid hydrolysis. There is thus a need of potent inhibitors of endocannabinoid degradation. Ten years after the first observation of an enzyme responsible of endocannabinoid hydrolysis, huge progresses have been accomplished in the characterisation of these enzymes. Three enzymes have now been identified, namely fatty acid amide hydrolase, monoglyceride lipase and $N$-palmitoylethanolamine-selective amidase. Their remarkable selectivity for the major actors of the endocannabinoid signalling suggest that the endocannabinoid system is a complex machinery in which the function of each component is dependent of the others. AEA and 2-AG may activate the cannabinoid receptors in the extracellular medium and when the $\mathrm{CB}$ activation is no longer required, be uptaken into the cell to be hydrolysed. PEA does not bind to the $\mathrm{CB}$ receptors but it can act as an endogenous regulator of the AEA and 2-AG levels by "entourage effect" or bind to a specific receptor, which is not yet known. Nevertheless, evidences now exist that in vivo inhibition of the endocannabinoid degradation leads to antinociception, hypotension and modulation of anxiety. These results prove that inhibition of endocannabinoid degradation is a promising way in the discovery of new medicines.

\section{REFERENCES}

References 204-206 are related articles recently published in Current Pharmaceutical Design.

[1] Matsuda LA, Lolait SJ, Brownstein MJ, Young AC, Bonner TI. Structure of a cannabinoid receptor and functional expression of the cloned cDNA. Nature 1990; 346: 561-4.
[2] Pertwee RG. Pharmacology of cannabinoid $\mathrm{CB}_{1}$ and $\mathrm{CB}_{2}$ receptors. Pharmacol Ther 1997; 74: 129-80.

[3] Pertwee RG. Neuropharmacology and therapeutic potential of cannabinoids. Addict Biol 2000; 5: 37-46.

[4] Munro S, Thomas KL, Abu-Shaar M. Molecular characterization of a peripheral receptor for cannabinoids. Nature 1993; 365: 61-5.

[5] Galiègue S, Mary S, Marchand J, Dussossoy D, Carrière D, Carayon P, et al. Expression of central and peripheral cannabinoid receptors in human immune tissues and leukocyte subpopulations. Eur J Biochem 1995; 232: 54-61.

[6] Devane WA, Hanus L, Breuer A, Pertwee RG, Stevenson LA, Griffin $\mathrm{G}$, et al. Isolation and structure of a brain constituent that binds to the cannabinoid receptor. Science 1992; 258: 1946-9.

[7] Fride E, Mechoulam R. Pharmacological activity of the cannabinoid receptor agonist, anandamide, a brain constituent. Eur J Pharmacol 1993; 231: 313-4.

[8] Mackie K, Devane WA, Hille B. Anandamide, an endogenous cannabinoid, inhibits calcium currents as a partial agonist in N18 neuroblastoma cells. Mol Pharmacol 1993; 44: 498-503.

[9] Vogel Z, Barg J, Levy R, Saya D, Heldman E, Mechoulam R. Anandamide, a brain endogenous compound, interacts specifically with cannabinoid receptors and inhibits adenylate cyclase. J Neurochem 1993; 61: 352-5.

[10] Jaggar SI, Hasnie FS, Sellaturay S, Rice AS. The anti-hyperalgesic actions of the cannabinoid anandamide and the putative $\mathrm{CB}_{2}$ receptor agonist palmitoylethanolamide in visceral and somatic inflammatory pain. Pain 1998; 76: 189-99.

[11] Calignano A, La Rana G, Giuffrida A, Piomelli D. Control of pain initiation by endogenous cannabinoids. Nature 1998; 394: 277-81.

[12] Vivian JA, Kishioka S, Butelman ER, Broadbear J, Lee KO, Woods JH. Analgesic, respiratory and heart rate effects of cannabinoid and opioid agonists in rhesus monkeys: antagonist effects of SR 141716A. J Pharmacol Exp Ther 1998; 286: 697-703.

[13] Smith FL, Fujimori K, Lowe J, Welch SP. Characterization of delta9-tetrahydrocannabinol and anandamide antinociception in nonarthritic and arthritic rats. Pharmacol Biochem Behav 1998; 60: $183-91$.

[14] Richardson JD, Aanonsen L, Hargreaves KM. Antihyperalgesic effects of spinal cannabinoids. Eur J Pharmacol 1998; 345: 145-53.

[15] Richardson JD, Kilo S, Hargreaves KM. Cannabinoids reduce hyperalgesia and inflammation via interaction with peripheral $\mathrm{CB}_{1}$ receptors. Pain 1998; 75: 111-9.

[16] Jaggar SI, Sellaturay S, Rice AS. The endogenous cannabinoid anandamide, but not the $\mathrm{CB}_{2}$ ligand palmitoylethanolamide, prevents the viscero-visceral hyperreflexia associated with inflammation of the rat urinary bladder. Neurosci Lett 1998; 253: $\underline{123-6 .}$

[17] Pertwee RG. Cannabinoid receptors and pain. Prog Neurobiol 2001; 63: 569-611. 
[18] Rice AS, Farquhar-Smith WP, Nagy I. Endocannabinoids and pain: spinal and peripheral analgesia inflammation and neuropathy. Prostaglandins Leukot Essent Fatty Acids 2002; 66: 243-56.

[19] Maccarrone M, Lorenzon T, Bari M, Melino G, Finazzi-Agro A. Anandamide induces apoptosis in human cells via vanilloid receptors. Evidence for a protective role of cannabinoid receptors. J Biol Chem 2000; 275: 31938-45.

[20] Sarker KP, Obara S, Nakata M, Kitajima I, Maruyama I. Anandamide induces apoptosis of PC-12 cells: involvement of superoxide and caspase-3. FEBS Lett 2000; 472: 39-44.

[21] Mimeault M, Pommery N, Wattez N, Bailly C, Henichart JP. Antiproliferative and apoptotic effects of anandamide in human prostatic cancer cell lines: implication of epidermal growth factor receptor down-regulation and ceramide production. Prostate 2003; 56: $1-12$.

[22] Yamaji K, Pada Sarker K, Kawahara K, Lino S, Yamakuchi M, Abey K, et al. Anandamide induces apoptosis in human endothelial cells: its regulation system and clinical implications. Thromb Haemost 2003; 89: 875-84.

[23] Ligresti A, Bisogno T, Matias I, De Petrocellis L, Cascio MG, Cosenz D'argenio G, et al. Possible endocannabinoid control of colorectal cancer growth. Gastroenterology 2003; 125: 677-87.

[24] Melck D, Rueda D, Galve-Roperh I, De Petrocellis L, Guzman M, Di Marzo V. Involvement of the cAMP/protein kinase A pathway and of mitogen-activated protein kinase in the anti-proliferative effect of anandamide in human breast cancer cells. FEBS Lett 1999; 463: 235-40.

[25] Fowler CJ, Jonsson KO, Andersson A, Juntunen J, Jarvinen T, Vandevoorde S, et al. Inhibition of C6 glioma cell proliferation by anandamide, 1-arachidonoylglycerol, and by a water soluble phosphate ester of anandamide: variability in response and involvement of arachidonic acid. Biochem Pharmacol 2003; 66: 757-67.

[26] Maccarrone M, Finazzi-Agro A. The endocannabinoid system, anandamide and the regulation of mammalian cell apoptosis. Cell Death Differ 2003; 10: 946-55.

[27] Parolaro D, Massi P, Rubino T, Monti E. Endocannabinoids in the immune system and cancer. Prostaglandins Leukot Essent Fatty Acids 2002; 66: 319-32.

[28] Paria BC, Wang H, Dey SK. Endocannabinoid signalling in synchronizing embryo development and uterine receptivity for implantation. Chem Phys Lipids 2002; 121: 201-10

[29] Habayeb OM, Bell SC, Konje JC. Endogenous cannabinoids: metabolism and their role in reproduction. Life Sci 2002; 70: 196377.

[30] Castellano C, Cabib S, Palmisano A, Di Marzo V, Puglisi-Allegra $\mathrm{S}$. The effects of anandamide on memory consolidation in mice involve both D1 and D2 dopamine receptors. Behav Pharmacol 1997; 8: 707-12

[31] Mallet PE, Beninger RJ. The cannabinoid $\mathrm{CB}_{1}$ receptor antagonist SR 141716 A attenuates the memory impairment produced by $\Delta^{9}-$ tetrahydrocannabinol or anandamide. Psychophar-macology 1998; 140: 11-19.

[32] Castellano C, Ventura R, Cabib S, Puglisi-Allegra S. Straindependent effects of anandamide on memory consolidation in mice are antagonized by naltrexone. Behav Pharmacol 1999; 10: 453-7.

[33] Kim D, Thayer SA. Cannabinoids inhibit the formation of new synapses between hippocampal neurons in culture. J Neurosci 2001; 21: RC146.

[34] Izzo AA, Capasso F, Costagliola A, Bisogno T, Marsicano G, Ligresti A, et al. An endogenous cannabinoid tone attenuates cholera toxin-induced fluid accumulation in mice. Gastroenterology 2003; 125: 765-74.

[35] Kathuria S, Gaetani S, Fegley D, Valino F, Duranti A, Tontini A, et al. Modulation of anxiety through blockade of anandamide hydrolysis. Nat Med 2003; 9: 76-81.

[36] Costa B, Parolaro D, Colleoni M. Chronic treatment with the endocannabinoid anandamide increases cytochrome P450 metabolizing system in the rat. Eur J Pharmacol 2002; 449: 61-9.

[37] Wallace MJ, Martin BR, DeLorenzo RJ. Evidence for a physiological role of endocannabinoids in the modulation of seizure threshold and severy. Eur J Pharmacol 2002; 452: 295-301.

[38] Gomez R, Navarro M, Ferrer B, Trigo JM, Bilbao A, Del Arco I, et al. A peripheral mechanism for $\mathrm{CB}_{1}$ cannabinoid receptordependent modulation of feeding. J Neurosci 2002; 22: 9612-7.
[39] Williams CM, Kirkham TC. Observational analysis of feeding induced by delta9-THC and anandamide. Physiol Behav 2002; 76: 241-50.

[40] Mechoulam R, Ben-Shabat S, Hanus L, Ligumsky M, Kaminski $\mathrm{NE}$, Schatz AR, et al. Identification of an endogenous 2monoglyceride, present in canine gut, that binds to cannabinoid receptors. Biochem Pharmacol 1995; 50: 83-90

[41] Sugiura T, Kondo S, Sukagawa A, Nakane S, Shinoda A, Itoh K, et al. 2-Arachidonoylglycerol: a possible endogenous cannabinoid receptor ligand in brain. Biochem. Biophys Res Commun 1995; 215: 89-97

[42] Stella N, Schweitzer P, Piomelli D. A second endogenous cannabinoid that modulates long-term potentiation. Nature 1997; 388: $773-8$

[43] Gonsiorek W, Lunn C, Fan X, Narula S, Lundell D, Hipkin RW. Endocannabinoid 2-arachidonyl glycerol is a full agonist through human type 2 cannabinoid receptor: antagonism by anandamide. Mol Pharmacol 2000; 57: 1045-50.

[44] Sugiura T, Kondo S, Kishimoto S, Miyashita T, Nakane S, Kodaka $\mathrm{T}$, et al. Evidence that 2-arachidonoylglycerol but not $\mathrm{N}$ palmitoylethanolamine or anandamide is the physiological ligand for the cannabinoid $\mathrm{CB}_{2}$ receptor. J Biol Chem 2000; 275: 605-12.

[45] Savinainen JR, Jarvinen T, Laine K, Laitinen JT. Despite substantial degradation, 2-arachidonoylglycerol is a potent full efficacy agonist mediating $\mathrm{CB}_{1}$ receptor-dependent G-protein activation in rat cerebellar membranes. Br J Pharmacol 2001; 134: 664-72.

[46] Melck D, De Petrocellis L, Orlando P, Bisogno T, Laezza C, Bifulco M, et al. Suppression of nerve growth factor Trk receptors and prolactin receptors by endocannabinoids leads to inhibition of human breast and prostate cancer cell proliferation. Endocrinology 2000; 141: 118-26.

[47] Mechoulam R, Fride E, Ben-Shabat S, Meiri U, Horowitz M. Carbachol, an acetylcholine receptor agonist, enhances production in rat aorta of 2-arachidonoyl glycreol, a hypotensive endocannabinoid. Eur J Pharmacol 1998; 362: R1-R3.

[48] Jarai Z, Wagner JA, Goparaju SK, Wang L, Razdan RK, Sugiura T, et al. Cardiovascular effects of 2-arachidonoyl glycerol in anesthetized mice. Hypertension 2000; 35: 679-84.

[49] Kojima SI, Sugiura T, Waku K, Kamikawa Y. Contractile response to a cannabimimetic eicosanoid, 2-arachidonoylglycerol, of longitudinal smooth muscle from the guinea-pig distal colon in vitro. Eur J Pharmacol 2002; 444: 203-7.

[50] Panikashvili D, Simeonidou C, Ben-Shabat S, Hanus L, Breuer A, Mechoulam R, et al. An endogenous cannabinoid (2-AG) is neuroprotective after brain injury. Nature 2001; 413: 527-31.

[51] Yamagushi T, Hagiwara Y, Tanaka H, Sugiura T, Waku K, Shoyama $\mathrm{Y}$, et al. Endogenous cannabinoid, 2arachidonoylglycerol, attenuates naloxone-precipitated withdrawal signs in morphine-dependent mice. Brain Res 2001; 909: 121-6.

[52] Stefano GB, Bilfinger TV, Rialas CM, Deutsch DG. 2-arachidonylglycerol stimulates nitric oxide release from human immune and vascular tissues and invertebrate immunocytes by cannabinoid receptor 1. Pharmacol Res 2000; 42: 317-22.

[53] Fride E. Role of $\mathrm{CB}_{1}$ receptor in newborn feeding and survival: maintenance of ultrasonic distress and body temperature. Symposium on the cannabinoids, Burlington, Vermont, International cannabinoid research society. 2003; pp. 37.

[54] Hanus L, Saleh AL, Fride E, Breuer A, Vogel A, Shalev DE, et al. 2-arachidonoyl glyceryl ether, an endogenous agonist of the cannabinoid $\mathrm{CB}_{1}$ receptor. Proc Natl Acad Sci USA 2001; 98: 3662-5.

[55] Milton NGN. Anandamide and noladin ether prevent neurotoxicity of the human amyloid- $\beta$ peptide. Neurosci Lett 2002; 332: 127-30.

[56] Oka S, Tsuchie A, Tokumura A, Muramatsu M, Suhara Y, Takayama $\mathrm{H}$, et al. Ether-linked analogue of 2-arachidonoylglycerol (noladin ether) was not detected in the brains of various mammalian species. J Neurochem 2003; 85: 1374-81.

[57] Porter AC, Sauer JM, Knierman MD, Becker GW, Berna MJ, Bao $\mathrm{J}$, et al. Characterization of a novel endocannabinoid, virodhamine, with antagonist activity at the $\mathrm{CB}_{1}$ receptor. J Pharmacol Exp Ther 2002; 301: 1020-4.

[58] Bisogno T, Melck D, Bodrov MY, Gretskaya NM, Bezuglov VV, De Petrocellis L, et al. N-acyl-dopamines: novel synthetic $\mathrm{CB}_{1}$ cannabinoid-receptor ligans and inhibitors of anandamide 
inactivation with cannabimimetic activity in vitro and in vivo. Biochem J 2000; 351: 817-27.

[59] Huang SM, Bisogno T, Trevisani M, Al-Hayani A, De Petrocellis L, Fezza F, et al. An endogenous capsaicin-like substance with high potency at recombinant and native vanilloid $\mathrm{VR}_{1}$ receptors. Proc Natl Acad Sci USA 2002; 99: 8400-5.

[60] Boger DL, Henriksen SJ, Cravatt BF. Oleamide: an endogenous sleep-inducing lipid and prototypical member of a new class of biological signalling molecules. Curr Pharm Des 1998; 4: 303-14.

[61] Leggett JD, Aspley S, Beckett SR, D’Antona AM, Kendall DA, Kendall DA. Oleamide is a selective endogenous agonist of rat and human CB1 cannabinoid receptors. Br J Pharmacol 2004; 141: 25362

[62] Mendelson WB, Basile AS. The hypnotic actions of oleamide are blocked by a cannabinoid receptor antagonist. Neuroreport 1999; 10: 3237-9.

[63] Ben-Shabat S, Fride E, Sheskin T, Tamiri T, Rhee MH, Vogel Z, et al. An entourage effect: inactive endogenous fatty acid glycerol esters enhance 2-arachidonoyl-glycerol cannabinoid activity. Eur J Pharmacol 1998 ; 353: 23-31.

[64] Maccarrone M, Cartoni A, Parolaro D, Margonelli A, Massi P, Bari $\mathrm{M}$, et al. Cannabimimetic activity, binding, and degradation of stearoylethanolamide within the mouse central nervous system. Mol Cell Neurosci 2002; 21: 126-40.

[65] Facci L, Dal Toso R, Romanello S, Buriani A, Skaper SD, Leon A. Mast cells express a peripheral cannabinoid receptor with differential sensitivity to anandamide and palmitoylethanolamide. Proc Natl Acad Sci USA 1995; 92: 3376-80.

[66] Ross RA, Murphy VL, McKay NG, Ashford MLJ, Pertwee RG. In Essential fatty acids and eicosanoids: Invited papers from the $4^{\text {th }}$ international congress. Ed. Riemersma R.A., Armstrong R., Kelly R.W., Wilson R. 1999: 376-379. Champaign, IL, USA, AOCS Press.

[67] Lambert DM, Di Paolo FG, Sonveaux P, Kanyonyo M, Govaerts SJ, Hermans E, et al. Analogues and homologues of $\mathrm{N}-$ palmitoylethanolamide, a putative endogenous $\mathrm{CB}(2)$ cannabinoid, as potential ligands for the cannabinoid receptors. Biochim Biophys Acta 1999; 1440: 266-74.

[68] Mazzari S, Canella R, Petrelli L, Marcolongo G, Leon A. N-(2hydroxyethyl)hexadecanamide is orally active in reducing edema formation and inflammation hyperalgesia by down-modulating mast cell activation. Eur J Pharmacol 1996; 300: 227-36.

[69] Calignano A, La Rana G, Piomelli D. Antinociceptive activity of the endogenous fatty acid amide, palmitylethanolamide. Eur J Pharmacol 2001; 419: 191-8.

[70] Lambert DM, Vandevoorde S, Jonsson KO, Fowler CJ. The palmitoylethanolamide family: A new class of anti-inflammatory agents? Curr Med Chem 2002; 9: 663-74.

[71] Walker JM, Krey JF, Chu CJ, Huang SM. Endocannabinoids and related fatty acid derivatives in pain modulation. Chem Phys Lipids 2002; 121: 159-72.

[72] Lambert DM, Vandevoorde S, Diependaele G, Govaerts SJ, Robert AR. Anticonvulsant activity of N-palmitoylethanolamide, a putative endocannabinoid, in mice. Epilepsia 2001; 42: 321-7.

[73] De Petrocellis L, Bisogno T, Ligresti A, Bifulco M, Melck D, Di Marzo V. Effect on cancer cell proliferation of palmitoylethanolamide, a fatty acid amide interacting with both the cannabinoid and vanilloid systems. Fundam Clin Pharmacol 2002; 16: 297-302.

[74] Deutsch DG, Chin SA. Enzymatic synthesis and degradation of ananamide, a cannabinoid receptor agonist. Biochem Pharmacol 1993; 46: 791-6.

[75] Desarnaud F, Cadas H, Piomelli D. Anandamide amidohydrolase activity in rat brain microsomes. Identification and partial characterization. J Biol Chem 1995; 270: 6030-5.

[76] Ueda N, Kurahashi Y, Yamamoto S, Tokunaga T. Partial purification and characterization of the porcine brain enzyme hydrolyzing and synthesizing anandamide. J Biol Chem 1995; 270: 23823-7.

[77] Cravatt BF, Giang DK, Mayfield SP, Boger DL, Lerner RA, Gilula NB. Molecular characterization of an enzyme that degrades neuromodulatory fatty-acid amides. Nature 1996; 384: 83-7.

[78] Dinh TP, Carpenter D, Leslie FM, Freund TF, Katona I, Sensi SL, et al. Brain monoglyceride lipase participating in endocannabinoid inactivation. Proc Natl Acad Sci USA 2002; 99: 10819-24.
[79] Ueda N, Yamanaka K, Yamamoto S. Purification and characterization of an acid amidase selective for $\mathrm{N}$ palmitoylethanolamine, a putative endogenous anti-inflammatory substance. J Biol Chem 2001; 276: 35552-7.

[80] Giang DK, Cravatt BF. Molecular characterization of human and mouse fatty acid amide hydrolases. Proc Natl Acad Sci USA 1997; 94: 2238-42.

[81] Goparaju SK, Ueda N, Taniguchi K, Yamamoto S. Enzymes of porcine brain hydrolyzing 2-arachidonoylglycerol, an endogenous ligand of cannabinoid receptors. Biochem Pharmacol 1999; 57: 417-23.

[82] $\overline{\text { Ueda N }}$, Yamamoto S. Anandamide amidohydrolase (fatty acid amide hydrolase). Prostaglandins Other Lipid Mediat 2000; 61: 1928 .

[83] Ueda N, Puffenbarger RA, Yamamoto S, Deutsch DG. The fatty acid amide hydrolase. Chem Phys Lipids 2000; 108: 107-21.

[84] Bracey MH, Hanson MA, Masuda KR, Stevens RC, Cravatt BF. Structural adaptations in a membrane enzyme that terminates endocannabinoid signalling. Science 2002; 298: 1793-6.

[85] Shrestha R, Dixon RA, Chapman KD. Molecular identification of a functional homologue of the mammalian fatty acid amide hydrolase in Arabidopsis thaliana. J Biol Chem 2003; 278: 34990-7.

[86] Katayama K, Ueda N, Kurahashi Y, Suzuki H, Yamamoto S, Kato I. Distribution of anandamide amidohydrolase in rat tissues with special reference to small intestine. Biochim Biophys Acta 1997; 1347: 212-8.

[87] Park B, Gibbons HM, Mitchell MD, Glassa M. Identification of the $\mathrm{CB}_{1}$ cannabinoid receptor and fatty acid amide hydrolase (FAAH) in the human placenta. Placenta 2003; $24: 473-8$.

[88] Paria BC, Deutsch DG, Dey SK. The uterus is a potential site for anandamide synthesis and hydrolysis: differential profiles of anandamide synthase and hydrolase activities in the mouse uterus during the preiimplantation period. Mol Reprod Dev 1996; 45: 18392.

[89] Paria BC, Zhao X, Wang J, Das SK, Dey SK. Fatty-acid amide hydrolase is expressed in the mouse uterus and embryo during the preiimplantation period. Biol Reprod 1999; 60: 1151-7.

[90] Maccarrone M, Valensise H, Bari M, Lazzarin N, Romanini C, Finazzi-Agro A. Relation between decreased anandamide hydrolase concentrations in human lymphocytes and miscarriage. Lancet 2000; 355: 1326-9.

[91] Bisogno T, Delton-Vandenbroucke I, Milone A, Lagarde M, Di Marzo V. Biosynthesis and inactivation of $\mathrm{N}$-arachidonoylethanolamine (anandamide) and $\mathrm{N}$-docosahexaenoylethanolamine in bovine retina. Arch Biochem Biophys 1999; 370: 300-7.

[92] Yazulla S, Studholme KM, McIntosh HH, Deutsch DG. Immunocytochemical localization of cannabinoid $\mathrm{CB}_{1}$ receptor and fatty acid amide hydrolase in rat retina. J Comp Neurol 1999; 415: $\underline{80-90}$

[93] Matsuda S, Kanemitsu N, Nakamura A, Mimura Y, Ueda N, Kurahashi Y, et al. Metabolism of anandamide, an endogenous cannabinoid receptor ligand, in porcine ocular tissues. Exp Eye Res, 1997; 64: 707-11.

[94] Hillard CJ, Wilkison D, Edgemond W, Campbell W. Characterization of the kinetics and distribution of $\mathrm{N}$ arachidonoylethanolamine (anandamide) hydrolysis in rat brain. Biochim Biophys Acta 1995; 1257: 249-56.

[95] Tsou K, Nogueron MI, Muthian S, Sanudo-Pena MC, Hillard CJ, Deutsch DG, et al. Fatty acid amide hydrolase is located preferentially in large neurons in the rat central nervous system as revealed by immunohistochemistry. Neurosci Lett 1998; 254: 13740.

[96] Benito C, Núnez E, Tolón RM, Carrier EJ, Rábano A, Hillard CJ, et al. Cannabinoid $\mathrm{CB}_{2}$ receptors and fatty acid amide hydrolase are selectively overexpressed in neuritic plaque-associated glia in Alzheimer's disease brains. J Neurosci 2003; 23: 11136-41.

[97] Egertová M, Giang DK, Cravatt BF, Elphick MR. A new perspective on cannabinoid signalling: complementary localization of fatty acid amide hydrolase, and the $\mathrm{CB}_{1}$ receptor in rat brain. Proc R Soc Lond B Biol Sci 1998; 265: 2081-5.

[98] Egertová M, Cravatt BF, Elphick MR. Comparative analysis of fatty acid amide hydrolase and $\mathrm{CB}_{1}$ cannabinoid receptor expression in the mouse brain: evidence of a widespread role for fatty acid amide hydrolase in regulation of endocannabinoid signalling. Neuroscience 2003; 119: 481-95. 
[99] Maurelli S, Bisogno T, De Petrocellis L, Di Luccia A, Marino G, Di Marzo V. Two novel classes of neuroactive fatty acid amides are substrates for mouse neuroblastoma "anandamide amidohydrolase". FEBS Lett 1995; 377: 82-6.

[100] Bisogno T, Maurelli S, Melck D, De Petrocellis L, Di Marzo V. Biosynthesis, uptake and degradation of anandamide and palmitoylethanolamide in leukocytes. J Biol Chem 1997; 272: 3315-23.

[101] Jacobsson SO, Fowler CJ. Characterization of palmitoylethanolamide transport in mouse neuro-2a neuroblastoma and rat RBL$2 \mathrm{H} 3$ basophilic leukaemia cells: comparison with anandamide. $\mathrm{Br} \mathrm{J}$ Pharmacol 2001; 132: 1743-54.

[102] Maccarrone M, Van der Stelt M, Rossi A, Veldink GA, Vliegenthart JF, Agro AF. Anandamide hydrolysis by human cells in culture and brain. J Biol Chem 1998; 273: 32332-9.

[103] Omeir RL, Arreaza G, Deutsch DG. Identification of two serine residues involved in catalysis by fatty acid amide hydrolase. Biochem Biophys Res Commun 1999; 264: 316-20.

[104] De Petrocellis L, Bisogno T, Maccarrone M, Davis JB, FinazziAgrò A, Di Marzo V. The activity of anandamide at vanilloid $\mathrm{VR}_{1}$ receptors requires facilitated transport across the cell membrane and is limited by intracellular metabolism. J Biol Chem 2001; 276: 12856-63.

[105] Bensinger JW, Li J, Porter AC. Characterization of anandamide and $\mathrm{N}$-arachidonoyldopamine activity at the human vanilloid receptor. Symposium on the cannabinoids, Burlington, Vermont, International cannabinoid research society. 2003; pp. 84.

[106] Maccarrone M, Bari M, Agro AF. A sensitive and specific radiochromatographic assay of fatty acid amide hydrolase. Anal Biochem 1999; 267: 314-8.

[107] Omeir RL, Chin S, Hong Y, Ahern DG, Deutsch DG. Arachidonoyl ethanolamide-1, $2-{ }^{14}$ Cas a substrate for anandamide amidase. Life Sci 1995; 56: 1999-2005.

[108] Fowler CJ, Tiger G, Stenström A. Ibuprofen inhibits rat brain deamidation of anandamide at pharmacologically relevant concentrations. Mode of inhibition and structure-activity relationship. J Pharmacol Exp Ther 1997; 283: 729-34.

[109] Wilson SJ, Lovenberg TW, Barbier AJ. A high-throughputcompatible assay for determining the activity of fatty acid amide hydrolase. Anal Biochem 2003; 318: 270-5.

[110] Watanabe K, Ogi H, Nakamura S, Kayano Y, Matsunaga T, Yoshimura $\mathrm{H}$, et al. Distribution and characterization of anandamide amidohydrolase in mouse brain and liver. Life Sci 1998; 62: 1223-9.

[111] Lang W, Qin C, Hill WA, Lin S, Khanolkar AD, Makriyannis A. High-performance liquid chromatographic determination of anandamide amidase activity in rat brain microsomes. Anal Biochem 1996; 238: 40-45 Erratum on Anal Biochem 1996; 241: 74.

[112] Goparaju SK, Ueda N, Yamaguchi H, Yamamoto S. Anandamide amidohydrolase reacting with 2-arachidonoylglycerol, another cannabinoid receptor ligand. FEBS Lett 1998; 422: 69-73.

[113] Qin C, Lin S, Lang W, Goutopoulos A, Pavlopoulos S, Mauri F, et $a l$. Determination of anandamide amidase activity using ultravioletactive amine derivatives and reverse-phase high-performance liquid chromatography. Anal Biochem 1998; 261: 8-15.

[114] Thumser AE, Voysey J, Wilton DC. A fluorescence displacement assay for the measurement of arachidonoyl ethanolamide (anandamide) and oleoyl amide (octadecenoamide) hydrolysis. Biochem Pharmacol 1997; 53: 433-5.

[115] Patricelli MP, Cravatt BF. Characterization and manipulation of the acyl chain selectivity of fatty acid amide hydrolase. Biochemistry 2001; 40: 6107-15.

[116] Deutsch DG, Ueda N, Yamamoto S. The fatty acid amide hydrolase. Prostaglandins Leukot Essent Fatty Acids 2002; 66: 201-10.

[117] Schmid PC, Zuzarte-Augustin ML, Schmid HHO. Properties of rat liver N-acylethanolamine amidohydrolase. J Biol Chem 1985; 260: 14145-9.

[118] Patricelli MP, Cravatt BF. Fatty acid amide hydrolase competitively degrades bioactive amides and esters through a nonconventional catalytic mechanism. Biochemistry 1999; 38: 14125-30.

[119] Goparaju SK, Kurahashi Y, Suzuki H, Ueda N, Yamamoto S. Anandamide amidohydrolase of porcine brain: cDNA cloning, functionnal expression and site-directed mutagenesis. Biochim Biophys Acta 1999; 1441: 77-84.

[120] Patricelli MP, Lovato MA, Cravatt BF. Chemical and mutagenic investigations of fatty acid amide hydrolase: evidence for a family of serine hydrolases with distinct cataytic properties. Biochemistry 1999; 38: 9804-12.

[121] Patricelli MP, Cravatt BF. Clarifying the catalytic roles of conserved residues in the amidase signature family. $\mathrm{J}$ Biol Chem 2000; 75: 19177-84.

[122] Mc Kinney MK, Cravatt BF. Evidence for distinct roles in catalysis for residues of the serine-serine-lysine catalytic triad of fatty acid amide hydrolase, J Biol Chem 2003; 278: 37393-9.

[123] Devane WA, Axelrod J. Enzymatic synthesis of anandamide, an endogenous ligand for the cannabinoid receptor, by brain membranes. Proc Natl Acad Sci USA 1994; 91: 6698-701.

[124] Kruszka K $\overline{\mathrm{K}}$, Gross RW. The ATP- and CoA- independent synthesis of arachidonoylethanolamide. A novel mechanism underlying the synthesis of the endogenous ligand of the cannabinoid receptor. J Biol Chem 1994; 269: 14345-8.

[125] Katayama K, Ueda N, Katoh I, Yamamoto S. Equilibrium in the hydrolysis and synthesis of cannabimimetic anandamide demonstrated by a purified enzyme. Biochim Biophys Acta 1999; 1440: 205-14

[126] Schmid PC, Reddy PV, Natarajan V, Schmid HHO. Metabolism of $\mathrm{N}$-acylethanolamine phospholipids by a mammalian phosphodiesterase of the phospholipase D type. J Biol Chem 1983; 258: 9302-6.

[127] Okamoto Y, Morishita J, Tsuboi K, Tonai T, Ueda N. Molecular characterization of a phospholipase D generating anandamide and its congeners. J Biol Chem 2004; 279: 5298-305.

[128] Piomelli D, Giuffrida A, Calignano A, de Fonseca FR. The endocannabinoid system as a target for therapeutic drugs. Trends Pharmacol Sci 2000; 21: 218-24.

[129] Fowler CJ. Plant-derived, synthetic and endogenous cannabinoids as neuroprotective agents. Non-psychoactive cannabinoids, 'entourage' compounds and inhibitors of $\mathrm{N}$-acyl ethanolamine breakdown as therapeutic strategies to avoid psychotropic effects. Brain Res Rev 2003; 41: 26-43.

[130] Cravatt BF, Lichtman AH. Fatty acid amide hydrolase: an emerging therapeutic target in the endocannabinoid system. Curr Opin Chem Biol 2003; 7: 469-75.

[131] Deutsch DG, Omeir R, Arreaza G, Salehani D, Prestwich GD, Huang Z, et al. Methyl arachidonyl fluorophosphonate: a potent irreversible inhibitor of anandamide amidase. Biochem Pharmacol 1997; 53: 255-60.

[132] De Petrocellis L, Melck D, Ueda N, Maurelli S, Kurahashi Y, Yamamoto $\mathrm{S}$, et al. Novel inhibitors of brain, neuronal and basophilic anandamide amidohydrolase. Biochem Biophys Res Commun 1997; 231: 82-8.

[133] Edgemond WS, Greenberg MJ, McGinley PJ, Muthian S, Campbell WB, Hillard CJ. Synthesis and characterization of diazomethylarachidonyl ketone: an irreversible inhibitor of $\mathrm{N}$-arachidonylethanolamine amidohydrolase. J Pharmacol Exp Ther 1998; 286: 184-90.

[134] Deutsch DG, Lin S, Hill WAG, Morse KL, Salehani D, Arreaza G, et al. Fatty acid sulfonyl fluorides inhibit anandamide metabolism and bind to the cannabinoid receptor. Biochem Biophys Res Commun 1997; 231: 217-21

[135] Martin BR, Beletskaya I, Patrick G, Jefferson R, Winckler R, Deutsch DG, et al. Cannabinoid properties of methylfluorophosphonate analogs. J Pharmacol Exp Ther 2000; 294: 1209-18.

[136] Segall Y, Quistad GB, Nomura DK, Casida JE. Arachidonylsulfonyl derivatives as cannabinoid $\mathrm{CB}_{1}$ receptor and fatty acid amide hydrolase inhibitors. Bioorg Med Chem Lett 2003; 13: 33013.

[137] Patricelli MP, Patterson JE, Boger DL, Cravatt BF. An endogenous sleep-inducing compound is a novel competitive inhibitor of fatty acid amide hydrolase. Bioorg Med Chem Lett 1998; 8: 613-8.

[138] Beltramo M, di Tomaso E, Piomelli D. Inhibition of anandamide hydrolysis in rat brain tissue by (E)-6-(bromomethylene) tetrahydro-3-(1-napthtalenyl)-2H-pyrano-2-one. FEBS Lett 1997; 403: 263-7.

[139] Tarzia G, Duranti A, Tontini A, Piersanti G, Mor M, Rivara S, et al. Design, synthesis, and structure-activity relationships of alkylcarbamic acid aryl esters, a new class of fatty acid amide hydrolase inhibitors. J Med Chem 2003; 46: 2352-60. 
[140] Koutek B, Prestwich GD, Howlett AC, Chin SA, Salehani D, Akhavan $\mathrm{N}$, et al. Inhibitors of arachidonoylethanolamide hydrolysis. J Biol Chem 1994; 269: 22937-40.

[141] Patterson JE, Ollmann IR, Cravatt BF, Boger DL, Wong CH, Lerner RA. Inhibition of oleamide hydrolase catalyzed hydrolysis of the endogenous sleep-inducing lipid cis-9-octadecenamide. J Am Chem Soc 1996; 118: 5938-45.

[142] Jonsson KO, Vandevoorde S, Lambert DM, Tiger G, Fowler CJ. Effects of homologues and analogues of palmitoylethanolamide upon the inactivation of the endocannabinoid anandamide. $\mathrm{Br} \mathrm{J}$ Pharmacol 2001; 133: 1263-75.

[143] Di Marzo V, Melck D, Orlando P, Bisogno T, Zagoory O, Bifulco $\mathrm{M}$, et al. Palmitoylethanolamide inhibits the expression of fatty acid amide hydrolase and enhances the anti-proliferative effect of anandamide in human breast cancer cells. Biochem J 2001; 358: 249-55.

[144] Vandevoorde S, Jonsson KO, Fowler CJ, Lambert DM. Modification of the ethanolamine head in N-palmitoylethanolamine: synthesis and evaluation of new agents interfering with the metabolism of anandamide. J Med Chem 2003; 46: 1440-8.

[145] Holt S, Nilsson J, Omeir R, Tiger G, Fowler CJ. Effects of pH on the inhibition of fatty acid amidohydrolase by ibuprofen. $\mathrm{Br} \mathrm{J}$ Pharmacol 2001; 133: 513-20 and 2001; 134: 451.

[146] Bisogno T, Melck D, De Petrocellis L, Yu Bodrov M, Gretskaya NM, Bezuglov VV, et al. Arachidonoylserotonin and other novel inhibitors of fatty acid amide hydrolase. Biochem Biophys Res Commun 1998; 248: 515-22.

[147] Boger DL, Sato H, Lerner AE, Hedrick MP, Fecik RA, Miyauchi $\mathrm{H}$, et al. Exceptionally potent inhibitors of fatty acid amide hydrolase: the enzyme responsible for degradation of endogenous oleamide and anandamide. Proc Natl Acad Sci USA 2000; 97: 5044-9.

[148] van der Stelt M, van Kuik JA, Bari M, van Zadelhoff G, Leeflang BR, Veldink GA, et al. Oxygenated metabolites of anandamide and 2-arachidonoylglycerol: conformational analysis and interaction with cannabinoid receptors, membrane transporter, and fatty acid amide hydrolase. J Med Chem 2002; 45: 3709-20.

[149] Boger DL, Miyauchi H, Hedrick MP. $\alpha$-keto heterocycle inhibitors of fatty acid amide hydrolase: carbonyl group modification and $\alpha$ substitution. Bioorg Med Chem Lett 2001; 11: 1517-20.

[150] Boger DL, Sato H, Lerner AE, Austin BJ, Patterson JE, Patricelli MP, et al. Trifluoromethyl ketone inhibitors of fatty acid amide hydrolase: a probe of structural and conformational features contributing to inhibition. Bioorg Med Chem 1999; 9: 265-70.

[151] Watanabe K, Kayano Y, Matsunaga T, Yamamoto I, Yoshimura H. Inhibition of anandamide amidase activity in mouse brain microsomes by cannabinoids. Biol Pharm Bull 1996; 19: 1109-11.

[152] Bisogno T, Hanus L, De Petrocellis L, Tchilibon S, Ponde DE, Brandi I, et al. Molecular targets for cannabidiol ant its synthetic analogues: effect on vanilloid $\mathrm{VR}_{1}$ receptors and on the cellular uptake and enzymatic hydrolysis of anandamide. Br J Pharmacol 2001; 134: 845-52.

[153] Rhee MH, Vogel Z, Barg J, Bayewitch M, Levy R, Hanus L, et al. Cannabinol derivatives: binding to cannabinoid receptors and inhibitions of adenylylcyclase. J Med Chem 1997; 40: 3228-33.

[154] Rinaldi-Carmona M, Barth F, Héaulme M, Shire D, Calandra B, Congy C, et al. SR 141716A, a potent and selective antagonist of the brain cannabinoid receptor. FEBS Lett 1994; 350: 240-4.

[155] Watanabe K, Ogi H, Nakamura S, Kayano Y, Matsunaga T, Yoshimura $\mathrm{H}$, et al. Distribution and characterization of anandamide amidohydrolase in mouse brain and liver. Life Sci 1998; 62: 1223-9.

[156] Fowler CJ, Janson U, Johnson RM, Wahlström G, Stenström A, Norström A, et al. Inhibition of anandamide hydrolysis by the enantiomers of ibuprofen, ketorolac and flurbiprofen. Arch Biochem Biophys 1999; 362: 191-6.

[157] Fowler CJ, Börjesson M, Tiger G. Differences in the pharmacological properties of rat and chicken brain fatty acid amidohydrolase. Br J Pharmacol 2000 ; 131: 498-504.

[158] Patel S, Wohlfeil ER, Rademacher DJ, Carrier EJ, Perry LTJ, Kundu A, et al. The general anesthetic propofol increases brain Narachidonoylethanolamine (anandamide) content and inhibits fatty acid amide hydrolase. Br J Pharmacol 2003 ; 139: 1005-13.

[159] Cravatt BF, Demarest K, Patricelli MP, Bracey MH, Giang DK, Martin BR, et al. Supersensitivity to anandamide and enhanced endogenous cannabinoid signalling in mice lacking fatty acid amide hydrolase. Proc Natl Acad Sci USA 2001; 98: 9371-6.

[160] Clement AB, Hawkins EG, Lichtman AH, Cravatt BF. Increased seizure susceptibility and proconvulsant activity of anandamide in mice lacking fatty acid amide hydrolase. J Neurosci 2003; 23: 3916-23.

[161] Tornqvist H, Belfrage P. Purification and some properties of a monoacylglycerol-hydrolyzing enzyme of rat adipose tissue. J Biol Chem 1976; 251: 813-9.

[162] Konrad RJ, Major CD, Wolf BA. Diacylglycerol hydrolysis to arachidonic acid is necessary for insulin secretion from isolated pancreatic islets: sequential actions of diacylglycerol and monoacylglycerol lipases. Biochemistry 1994; 33: 13284-94.

[163] Di Marzo V, Bisogno T, De Petrocellis L, Melck D, Orlando P, Wagner JA, et al. Biosynthesis and inactivation of the endocannabinoid 2-arachidonoylglycerol in circulating and tumoral macrophages. Eur J Biochem 1999; 264: 258-67.

[164] Karlsson M, Contreras JA, Hellman U, Tornquist H, Holm C. cDNA cloning, tissue distribution, and identification of the catalytic triad of monoglyceride lipase. J Biol Chem 1997; 272: 27218-23.

[165] Karlsson M, Reue K, Xia YR, Lusis AJ, Langin D, Tornqvist H, et al. Exon-intron organization and chromosomal localization of the mouse monoglyceride lipase gene. Gene 2001; 272: 11-8.

[166] Jarai Z, Wagner JA, Goparaju SK, Wang L, Razdan RK, Sugiura T, et al. Cardiovascular effect of 2-arachidonoyl glycerol in anesthetized mice. Hypertension 2000; 35: 679-84.

[167] Lichtman AH, Hawkins EG, Griffin G, Cravatt BF. Pharmacological activity of fatty acid amides is regulated, but not mediated, by fatty acid amide hydrolase in vivo. J Pharmacol Exp Ther 2002; 302: 73-9.

[168] Di Marzo V, Bisogno T, Sugiura T, Melck D, De Petrocellis L. The novel endogenous cannabinoid 2-arachidonoylglycerol is inactivated by neuronal- and basophil-like cells: connections with anandamide. Biochem J 1998; 331: 15-9.

[169] Ueda N, Yamanaka K, Yamamoto S. Purification and characterization of an acid amidase selective for $\mathrm{N}$-palmitoylethanolamine, a putative endogenous anti-inflammatory substance. J Biol Chem 200; 276: 35552-7.

[170] Tsuboi K, Hilligsmann C, Vandevoorde S, Lambert DM, Ueda N. $\mathrm{N}$-cyclohexanecarbonylpentadecylamine: a selective inhibitor of the acid amidase hydrolyzing $\mathrm{N}$-acylethanolamines, as a tool to distinguish acid amidase from fatty acid amide hydrolase. Biochem J 2004; 379: 99-106.

[171] Vandevoorde S, Tsuboi K, Ueda N, Jonsson KO, Fowler CJ, Lambert DM. Esters, retroesters and a retroamide of palmitic acid: pool for the first selective inhibitors of N-palmitoylethanolamineselective acid amidase. J Med Chem 2003; 46: 4373-6.

[172] Hillard CJ, Jarrahian A. The movement of N-arachidonoylethanolamine (anandamide) across cellular membranes. Chem Phys Lipids 2000; 108: 123-34.

[173] Hillard CJ, Jarrahian A. Cellular accumulation of anandamide: consensus and controversy. Br J Pharmacol 2003;140: 802-808.

[174] Giuffrida A, Beltramo M, Piomelli D. Mechanisms of endocannabinoid inactivation: biochemistry and pharmacology. J Pharmacol Exp Ther 2001; 298: 7-14.

[175] Fowler CJ, Jacobsson SOP. Cellular transport of anandamide, 2arachidonoylglycerol and palmitoylethanolamide-targets for drug development? Prostaglandins Leukot Essent Fatty Acids 2002; 66: 193-200.

[176] Di Marzo V, Fontana A, Cadas H, Schinelli S, Cimino G, Schwartz $\mathrm{JC}$, et al. Formation and inactivation of endogenous cannabinoid anandamide in central neurons. Nature 1994; 372: 686-91.

[177] Hillard CJ, Edgemond WS, Jarrahian A, Campbell WB. Accumulation of $\mathrm{N}$-arachidonoylethanolamide (anandamide) into cerebellar granule cells occurs via facilitated diffusion. J Neurochem 1997; 69: 631-8.

[178] Beltramo M, Stella N, Calignano A, Lin SY, Makriyannis A, Piomelli D. Functional role of a high-affinity anandamide transport, as revealed by selective inhibition. Science 1997; 277: 1094-7.

[179] Piomelli D, Beltramo M, Glasnapp S, Lin SY, Goutopoulos A, Xie $\mathrm{XQ}$, et al. Structural determinants for recognition and translocation by the anandamide transporter. Proc Natl Acad Sci USA 1999; 96: $\underline{5802-7 .}$ 
[180] Maccarrone M, Bari M, Lorenzon T, Bisogno T, Di Marzo V, Finazzi-Agro A. Anandamide uptake by human endothelial cells and its regulation by nitric oxide. J Biol Chem 2000; 273: 32332-9.

[181] Rakhshan F, Day TA, Blakely RD, Berker EL. Carrier-mediated uptake of the endogenous cannabinoid anandamide in RBL-2H3 cells. J Pharmacol Exp Ther 2000; 292: 960-7.

[182] Day TA, Rakhshan F, Deutsch DG, Barker EL. Role of fatty acid amide hydrolase in the transport of the endogenous cannabinoid ananamide. Mol Pharmacol 2001; 59: 1369-75

[183] Deutsch DG, Glaser ST, Howell JM, Kunz JS, Puffenbarger RA, Hillard CJ, et al. The cellular uptake of anandamide is coupled to its breakdown by fatty-acid amide hydrolase. J Biol Chem 2001; 276: 6967-73.

[184] Bojesen IN, Hansen HS. Binding of anandamide to bovine serum albumin. J Lipid Res 2003; 44: 1790-4.

[185] Maccarrone M, Bari M, Menichelli A, Del Principe D, Finazzi Agrò A. Anandamide activates human platelets through a pathway independent of the arachidonate cascade. FEBS Lett 1999; 447: 277-82.

[186] Fasia L, Karava V, Siafaka-Kapadai A. Uptake and metabolism of ${ }^{3} \mathrm{H}$ ]-anandamide by rabbit platelets; lack of transporter? Eur J Biochem 2003; 270: 3498-506.

[187] Jarrahian A, Manna S, Edgemond WS, Campbell WB, Hillard CJ. Structure-activity relationships among $\mathrm{N}$-arachidonylethanolamine (anandamide) head group analogues for the anandamide transporter. J Neurochem 2000; 74: 2597-606.

[188] De Petrocellis L, Bisogno T, Davis JB, Pertwee RG, Di Marzo V. Overlap between the ligand recognition properties of the anandamide transporter and the $\mathrm{VR}_{1}$ vanilloid receptor: inhibitors of anandamide uptake with negligible capsaicin-like activity. FEBS Lett 2000; 483: 52-6.

[189] Chen WC, Huang JK, Cheng JS, Tsai JCR, Chiang AJ, Chou KJ, et al. AM404 elevates renal intracellular $\mathrm{Ca}^{2+}$, questioning its selectivity as a pharmacological tool for investigating the anandamide transporter. J Pharmacol Toxicol Methods 2001; 45: 195-8

[190] Calignano A, La Rana G, Beltramo M, Makriyannis A, Piomelli D. Potentiation of anandamide hypotension by the transport inhibitor, AM 404. Eur J Pharmacol 1997; 337: R1-2.

[191] Melck D, Bisogno T, De Petrocellis L, Chuang H, Julius D, Bifulco $\mathrm{M}$, et al. Unsaturated long-chain $\mathrm{N}$-acyl-vanillyl-amides (NAVAMs): vanilloid receptor ligands that inhibit anandamidefacilitated transport and bind to $\mathrm{CB}_{1}$ cannabinoid receptors. Biochem Biophys Res Commun 1999; 262: 275-84.

[192] Di Marzo V, Bisogno T, Melck D, Ross R, Brockie H, Stevenson $\mathrm{L}$, et al. Interactions between synthetic vanilloids and the endogenous cannabinoid system. FEBS Lett 1998; 436: 449-54.

[193] Di Marzo V, Breivogel C, Bisogno T, Melck D, Patrick G, Tao Q, et al. Neurobehavioral activity in mice of N-vanillyl-arachidonylamide. Eur J Pharmacol 2000; 406: 363-74.
[194] López-Rodríguez ML, Viso A, Ortega-Gutiérrez S, Lastres-Becker I, González S, Fernández-Ruiz J, et al. Design, synthesis and biological evaluation of novel arachidonic acid derivatives as highly potent and selective endocannabinoid transporter inhibitors. J Med Chem 2001; 44: 4505-8.

[195] López-Rodríguez ML, Viso A, Ortega-Gutiérrez S, Fowler CJ, Tiger G, de Lago E, et al. Design, synthesis and biological evaluation of new endocannabinoid transporter inhibitors. Eur $\mathbf{J}$ Med Chem 2003; 38: 403-12.

[196] López-Rodríguez ML, Viso A, Ortega-Gutiérrez S, Fowler CJ, Tiger G, de Lago E, et al. Design, synthesis and biological evaluation of new inhibitors of the endocannabinoid uptake: comparison with effects on fatty acid amidohydrolase. J Med Chem 2003; 46: 1512-22.

[197] de Lago E, Fernández-Ruiz J, Ortega-Gutiérrez S, Viso A, LópezRodríguez ML, Ramos JA. UCM707, a potent and selective inhibitor of endocannabinoid uptake, potentiates hypokinetic and antinociceptive effects of anandamide. Eur J Pharmacol 2002; 449: 99-103.

[198] Ortar G, Ligresti A, De Petrocellis L, Morera E, Di Marzo V. Novel selective and metabolically stable inhibitors of anandamide cellular uptake. Biochem Pharmacol 2003; 65: 1473-81.

[199] Battista N, Bari M, Finazzi-Agrò A, Maccarrone M. Anandamide uptake by synaptosomes from human, mouse and rat brain: inhibition by glutamine and glutamate. Lipids Health Dis 2002; $1(1)$.

[200] Jacobsson SOP, Fowler CJ. Characterisation of palmitoylethanolamide transport in mouse Neuro-2a neuroblastoma and rat RBL-2H3 basophilic leukaemia cells: comparison with anandamide. Br J Pharmacol 2001; 132: 1743-54.

[201] Beltramo M, Piomelli D. Carrier-mediated transport and enzymatic hydrolysis of the endogenous cannabinoid 2-arachidonoylglycerol. Neuroreport 2000; 11: 1231-5.

[202] Bisogno T, Maccarrone M, De Petrocellis L, Jarrahian A, FinazziAgrò A, Hillard C, et al. The uptake by cells of 2-arachidonoylglycerol, an endogenous agonist of cannabinoid receptors. Eur J Biochem 2001; 268: 1982-9.

[203] Maccarrone M, Bari M, Menichelli A, Giuliani E, Del Principe D, Finazzi-Agrò A. Human platelets bind and degrade 2-arachidonoylglycerol, which activates these cells through a cannabinoid receptor. Eur J Biochem 2001; 268: 819-25.

[204] Biegon A. Cannabinoids as neuroprotective agents in traumatic brain injury. Curr Pharm Design 2004; 10(18): 2177-83.

[205] Kozak KR, Prusakiewicz JJ, Marnett LJ. Oxidative metabolism of endocannabinoids by COX-2. Curr Pharm Design 2004; 10(6): 659-67.

[206] Reggio PH. Pharmacophores for ligand recognition and activation/inactivation of the cannabinoid receptors. Curr Pharm Design 2003; 9(20): 1607-33. 